\title{
The fossil record of the family Benthopectinidae (Echinodermata, Asteroidea), a reappraisal
}

\author{
Andy S. GALE ${ }^{1, *} \&$ John W.M. JAGT ${ }^{\circ} 2$ \\ ${ }^{1}$ Department of Earth Sciences, The Natural History Museum, Cromwell Road, \\ London SW7 5BD, United Kingdom. \\ ${ }^{1}$ School of the Environment, Geography and Geological Sciences, University of Portsmouth, \\ Burnaby Building, Burnaby Road, Portsmouth PO13QL, United Kingdom. \\ ${ }^{2}$ Natuurhistorisch Museum Maastricht, De Bosquetplein 6-7, 6211 KJ Maastricht, the Netherlands. \\ *Corresponding author: andy.gale@port.ac.uk \\ ${ }^{2}$ Email: john.jagt@maastricht.nl \\ ${ }^{1}$ urn:1sid:zoobank.org:author:092855B9-CBE4-41F9-9861-3BEA1FDE50F1 \\ ${ }^{2}$ urn:1sid:zoobank.org:author:39D4B31E-5847-4B03-94DF-2FF3E84C0B82
}

\begin{abstract}
Fossils assigned to the predominantly deep-sea asteroid family Benthopectinidae Verrill, 1894 are described and their affinities reappraised. Detailed comparative morphology of ambulacrals, adambulacrals and marginal ossicles has revealed that only some extinct taxa fall within the morphological range of the modern representatives of the family. These include Jurapecten hessi Gale, 2011, J. infrajurensis sp. nov. (both Jurassic), J. dhondtae sp. nov. (Upper Cretaceous) and Nearchaster spinosus (Blake, 1973) comb. nov. (Lower Oligocene). A new Late Cretaceous genus, Punkaster gen. nov. (P. spinifera gen. et sp. nov. and P. ruegenensis gen. et sp. nov.), appears to be a highly derived benthopectinid. A possible benthopectinid is described from the Upper Triassic (Carnian) of China. Other described records are distantly related to, but convergent in gross morphology with, benthopectinids. Thus, Plesiastropecten hallovensis Peyer, 1944 is here referred to the Jurassic spinulosidan family Plumasteridae Gale, 2011 and Xandarosaster hessi Blake, 1984 is interpreted as Spinulosida Perrier, 1884 incertae sedis. The mid-Cretaceous Alkaidia sumralli Blake \& Reid, 1998 is reassigned to the Forcipulatida (Zorocallina). The "fossil benthopectinid" of Spencer \& Wright in Moore (1966) is shown to belong to the goniopectinid genus Chrispaulia Gale, 2005, of which two new Cretaceous species are described, C. wrightorum sp. nov. and C. spinosa sp. nov. Finally, we consider Henricia? venturana Durham \& Roberts, 1948 to be an indeterminate asteroid.
\end{abstract}

Keywords. Neoasteroidea, Mesozoic, North America, Europe, new taxa.

Gale A.S. \& Jagt J.W.M. 2021. The fossil record of the family Benthopectinidae (Echinodermata, Asteroidea), a reappraisal. European Journal of Taxonomy 755: 149-190. https://doi.org/10.5852/ejt.2021.755.1405

\section{Introduction}

Benthopectinids form a small but well-characterised family of predominantly deep-sea asteroids, of very widespread distribution in the deeper bathyal and abyssal regions of the world's oceans. Eight 
genera are now recognised (Clark 1981; Clark \& Downey 1992), of which only two, Pontaster Sladen, 1885 and Cheiraster Studer, 1883, extend onto the continental shelves, and then only at high northern latitudes. Approximately 75 species are currently considered valid (Clark \& Downey 1992; Mah 2020a) and, although the taxonomy of benthopectinids has been described in considerable detail, their biology is poorly known. Gage et al. (1982) described the reproductive biology of three Atlantic species and concluded that they underwent direct development from large yolky eggs. The presence of special longitudinal muscles in the arms of benthopectinids has led to suggestions that they either swim or raise the arms for filter feeding. In-situ deep-sea photographs (Mah 2020b) show a partially buried specimen of Cheiraster cf. echinulatus (Perrier, 1875) with superomarginal spines projecting above the substrate. Mah (2020b) also recorded other (unnamed) benthopectinids sitting on open substrates.

Over the last 40 years, a number of authors have identified extinct species of asteroid as benthopectinids. In the Treatise of Invertebrate Paleontology, Spencer \& Wright (1966) recorded a fossil benthopectinid from the Albian (mid-Cretaceous) of the United Kingdom, but failed to provide more details. The specimen upon which this record was based is now in the C.W. and E.V. Wright Collection at the Natural History Museum, London (NHMUK). Blake (1973) described the ossicular morphology of benthopectinids for the first time, and recorded a new genus and species of benthopectinid, Mistia spinosa Blake, 1973, from the Lower Oligocene of Oregon. Subsequently, Blake (1984) identified two fossils from the Jurassic of Switzerland as benthopectinids, namely Plesiastropecten hallovensis Peyer, 1944 (of Hettangian age) and Xandarosaster hessi Blake, 1984 (of Bajocian age), which he placed in a new subfamily, the Paleobenthopectininae. In the same paper, he referred Henricia? venturana Durham \& Roberts, 1948, from the Cretaceous of California, to the benthopectinids. Villier et al. (2009) transferred Xandarosaster and Plesioastropecten to the Order Velatida Perrier, 1884. A further genus and species, Alkaidia sumralli Blake \& Reid, 1998, from the upper Albian-Cenomanian of Texas, was referred to the subfamily Paleobenthopectininae. This has subsequently been transferred to the forcipulatacean family Terminasteridae Gale, 2011 by Gale (2011a) and Ewin \& Gale (2020). Blake \& Jagt (2005) recorded a benthopectinid, Cheiraster? sp., from the upper Maastrichtian of the Netherlands, and Jagt (2000) had earlier identified two (or more) benthopectinid species, benthopectinid sp. 1 (? spp.) and benthopectinid sp. 2, on the basis of both isolated and associated ossicles from the upper Campanian and Maastrichtian of northeast Belgium, southeast Netherlands and the Aachen area (Germany). Gale (2011a, 2011b) described Jurapecten hessi from the Upper Jurassic (Oxfordian) of the French Jura, based on isolated and associated ossicle groups. ASG had previously collected further material of Jagt's "benthopectinid 2" from the Cenomanian-Campanian Chalk of England. Subsequently, we set about to describe this material, augmented by an associated set of ossicles from the uppermost Maastrichtian of Stevns Klint, eastern Denmark, herein described as Punkaster spinifera gen et sp. nov. From that study followed a reappraisal of the taxonomic affinities of all fossils so far assigned to the Benthopectinidae, their relationships with extant genera and the phylogeny of the family.

Two new species of the genus Jurapecten Gale, 2011 are described, one of Jurassic (middle Toarcian), the other of Cretaceous (late Maastrichtian) age, while Mistia spinosa is reassigned to the Recent genus Nearchaster Fisher, 1911. In addition, one new Late Cretaceous genus, Punkaster gen. nov. (with two species, P. spinifera gen. et sp. nov. and P. ruegenensis gen. et sp. nov.), which appears to be a highly derived benthopectinid, is erected. Plesiastropecten hallovensis Peyer, 1944 is reassigned to the Jurassic spinulosidan family Plumasteridae Gale, 2011, Xandarosaster hessi interpreted as Spinulosida incertae sedis and Alkaidia sumralli placed in the Forcipulatida Perrier, 1884 (Zorocallina Downey, 1970). Lastly, two new Cretaceous species of the goniopectinid genus Chrispaulia Gale, 2005 are erected, C. wrightorum sp. nov. and C. spinosa sp. nov., and Henricia? venturana is considered to be an indeterminate asteroid. 


\section{Material and methods}

The present study is based on fossil material contained in several North American and European museums (see list of institutional abbreviations below). Comparative Recent material of several taxa housed in a few institutional collections (Table 1) has also been used, as have partially macerated (bleach) specimens in the A.S. Gale Collection; the latter have not been formally registered. Specimens used for SEM examination were gold-palladium coated and imaged in a Jeol SEM.

Morphological terminology follows Gale (2011a, 2011b) and Ewin \& Gale (2020).

\section{Institutional abbreviations}

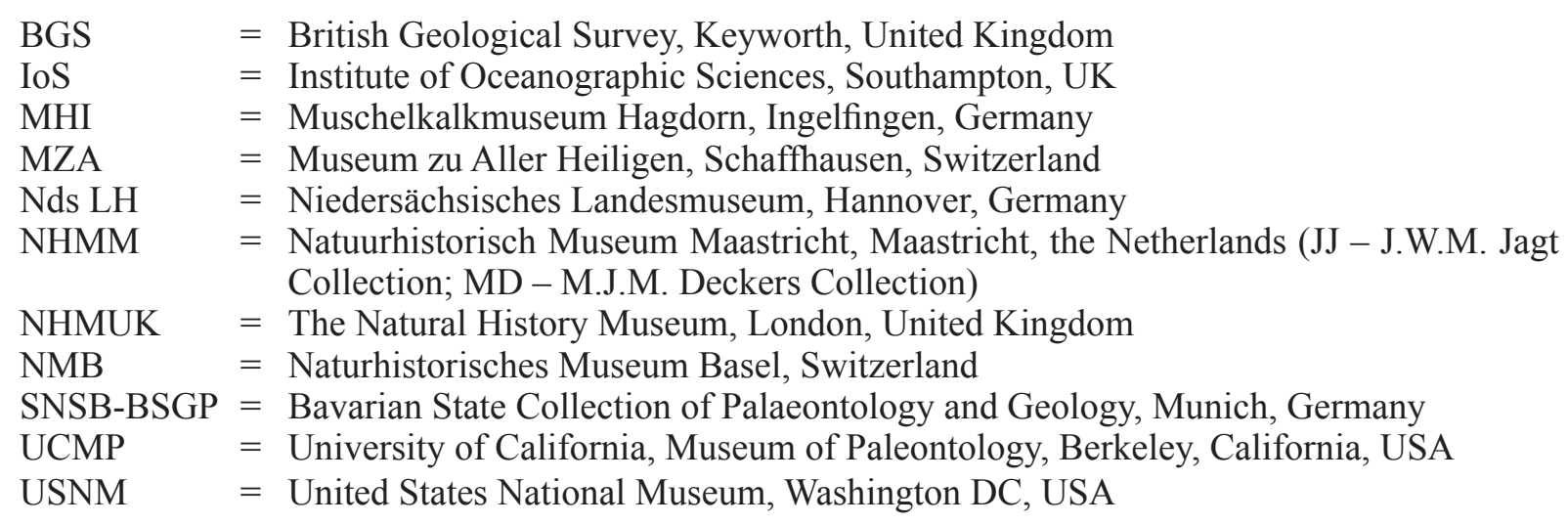

\section{Abbreviations for asteroid morphology}

$\begin{array}{ll}\text { ab } & =\text { abactinal ossicle } \\ \text { abiim } & =\text { abactinal interradial interoral muscle (oral) } \\ \text { abr } & =\text { abactinal ridge (on amb) } \\ \text { abtam } & =\text { abactinal transverse amb muscle } \\ \text { aciim } & =\text { actinal interradial interoral muscle } \\ \text { actam } & =\text { actinal transverse amb muscle } \\ \text { actf } & =\text { actinal face (of oral) } \\ \text { ad } & =\text { adambulacral ossicle } \\ \text { ada1 } & =\text { single distal amb-adamb articulation } \\ \text { ada1a } & =\text { distal adradial amb-adamb articulation } \\ \text { ada1b } & =\text { distal abradial amb-adamb articulation } \\ \text { ada2 } & =\text { proximal adradial amb-adamb articulation } \\ \text { ada3 } & =\text { proximal abradial adamb-amb or adamb-adamb articulation } \\ \text { adada } & =\text { adamb-adamb articulation } \\ \text { adadm } & =\text { interadambulacral muscle } \\ \text { adamb } & =\text { adambulacral } \\ \text { adp } & =\text { adambulacral process } \\ \text { adpm } & =\text { adambulacral prominence } \\ \text { amb } & =\text { ambulacral ossicle } \\ \text { ambb } & =\text { base of ambulacral ossicle } \\ \text { ambh } & =\text { head of ambulacral ossicle } \\ \text { ambsh } & =\text { shaft of ambulacral ossicle } \\ \text { amn } & =\text { ambulacral notch } \\ \text { apo } & =\text { apophyse on oral } \\ \text { car } & =\text { caries-like holes on articulation surfaces of amb, adamb } \\ \text { ce } & =\text { centrale } \\ \text { co } & =\text { circumoral ossicle } \\ \text { coh } & =\text { circumoral head } \\ \text { dadam } & =\text { distal amb-adamb muscle }\end{array}$




\begin{tabular}{|c|c|c|}
\hline dcoa & $=$ & distal circumoral articulation on oral \\
\hline dep & $=$ & distal circumoral process on circumoral \\
\hline de & $=$ & dentition (orals, ambs, peds) \\
\hline doda & $=$ & distal odontophore articulation (on oral, odontophore) \\
\hline fs & $=$ & furrow spine \\
\hline iioa & $=$ & interradial interoral articulation (on oral) \\
\hline im & $=$ & inferomarginal \\
\hline ima & $=$ & articulation surface between adjacent inferomarginals \\
\hline ma & $=$ & inferomarginal articulation \\
\hline lia & $=$ & longitudinal interamb articulation \\
\hline $\lim$ & $=$ & longitudinal interambulacral muscle \\
\hline $\mathrm{ms}$ & $=$ & marginal spine \\
\hline odom & $=$ & oral-odontophore muscle \\
\hline or & $=$ & oral ossicle \\
\hline orada & $=$ & adambulacral articulation (on oral) \\
\hline oradm & $=$ & oral adambulacral muscle \\
\hline osp & $=$ & attachment of oral spine \\
\hline padam & $=$ & proximal adamb-amb muscle \\
\hline $\mathrm{pb}$ & $=$ & proximal blade (oral ossicle) \\
\hline pcoa & $=$ & proximal oral-circumoral articulation \\
\hline pcp & $=$ & proximal circumoral process (on circumoral) \\
\hline pir & $=$ & primary interradial ossicle \\
\hline poda & $=$ & proximal odontophore articulation (on oral and odontophore) \\
\hline $\mathrm{pr}$ & $=$ & primary radial ossicle \\
\hline ra & $=$ & radial \\
\hline riom & $=$ & radial interoral muscle \\
\hline rng & $=$ & ring nerve groove on oral \\
\hline rvg & $=$ & ring vessel groove on oral \\
\hline sads & $=$ & subadambulacral spine \\
\hline sm & $=$ & superomarginal \\
\hline os & $=$ & attachment of suboral spine \\
\hline
\end{tabular}

\section{Results}

\section{Morphological characteristics of extant benthopectinids}

In basic construction, benthopectinids are similar to other Paxillosida Perrier, 1884 in possessing relatively elongated, tapering arms, with acutely angled to rounded interradii and conspicuous, spinebearing marginals that frame disc and arms and a flat abactinal surface that is made of small ossicles set in a flexible integument (Figs 1-2). Indeed, astropectinid taxa such as Dytaster Sladen, 1889, which bear single spines on each marginal ossicle and in which intermarginal fascioles are poorly developed, are superficially similar to benthopectinid genera like Pontaster. More detailed inspection of both the external and internal morphology, however, reveals that all extant benthopectinids share numerous distinctive characters; these are discussed below. Whether or not the presence of these justifies the elevation of the family to an order (i.e., Notomyotida Ludwig, 1910) has been the source of controversy amongst taxonomists. In the phylogeny of Gale (2011a), benthopectinids belong to the Paxillosida, sister group to the other four families making up the group. Molecular studies suggest that benthopectinids are sister taxon to the Pseudarchasteridae, and belong to a clade which includes all Paxillosida (Mah \& Foltz 2011: fig. 1).

Distinctive features of benthopectinids include the following:

- The presence of longitudinal muscles in the arms, which attach to specialised ridges on the ambulacrals (abr; see Fig. 3I), the dorsal body wall and the insides of the inferomarginals (Clark 1981). 
- Papulae (specialised respiratory structures) are restricted to specific regions, called papularia, at the base of the arms on the abactinal surface. These are oval, or V-shaped, stand proud of the surface and are made up of distinctively thickened, triangular abactinal ossicles between which the papulae extrude (Fig. 1A).

- The presence of distinctive comb-like, multivalved pectinate (attached to more than one ossicle) and fasciculate (attached to a single ossicle) pedicellariae, in the form of a double comb of two opposing rows of valves (Fisher 1911; Jangoux \& Lambert 1988). These bear a distinctive sculpture on the

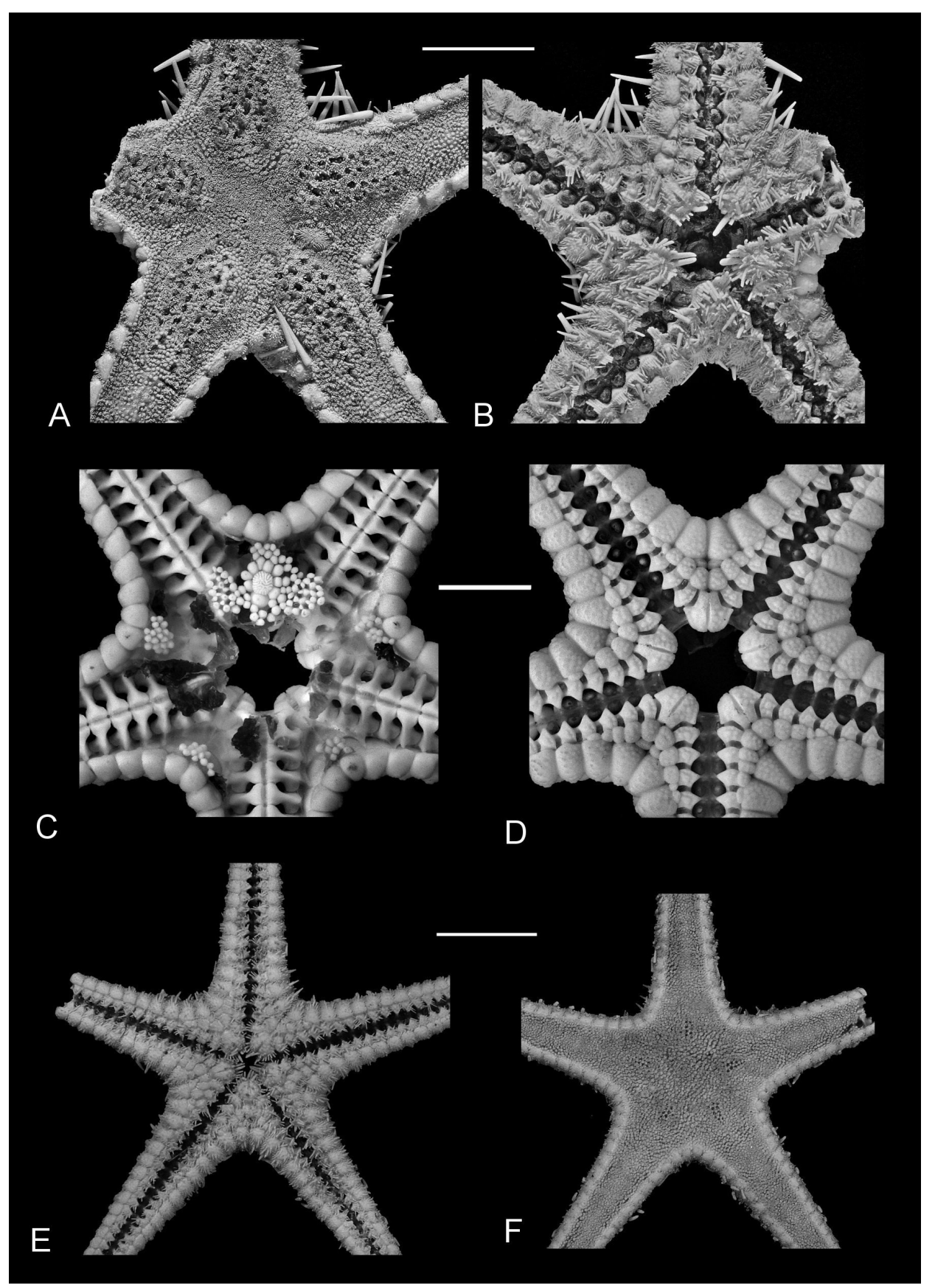

Fig. 1. A-B. Cheiraster gazellae Studer, 1883, Recent, in abactinal (A) and actinal (B) views (A.S. Gale collection, unregistered). C-F. Pontaster tenuispinus (von Düben \& Koren, 1846), Recent, in various views (A.S. Gale collection, unregistered), Rockall Trough, NE Atlantic. Scale bars: A-B = $7 \mathrm{~mm}$; $\mathrm{C}-\mathrm{D}=5 \mathrm{~mm} ; \mathrm{E}-\mathrm{F}=10 \mathrm{~mm}$. 
exterior of the valves. Pontaster has bivalved pedicellariae only (Clarke \& Downey 1992). The precise homology with pedicellariae in other asteroid groups is uncertain.

- The lateral surfaces of the ambulacrals articulate with the inner sides of the inferomarginals, except on the 4-5 most proximal plates (Fig. 4A).

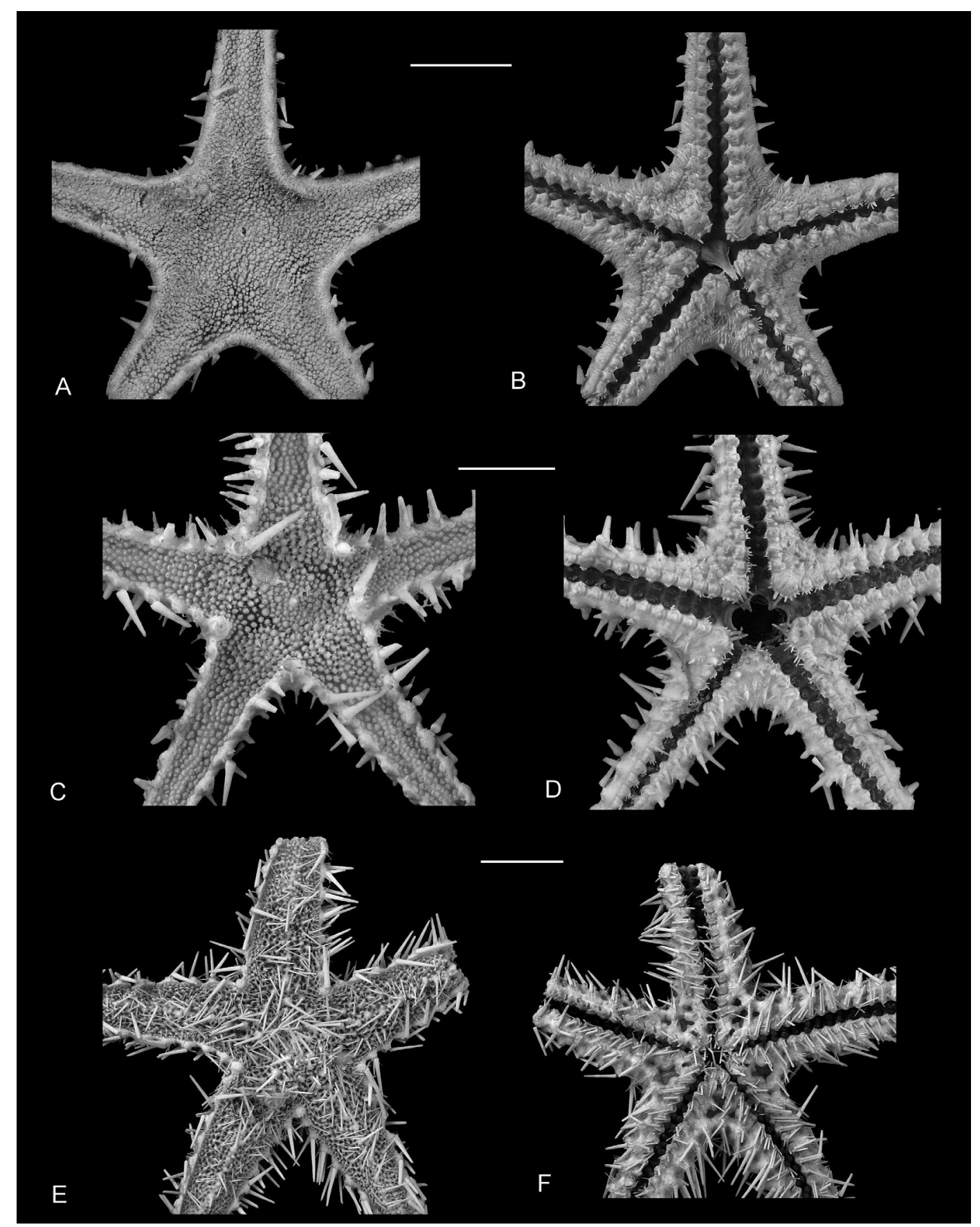

Fig. 2. A-B. Pectinaster filholi Perrier, 1885, Recent, in abactinal (A) and actinal (B) views, Porcupine Trough, NE Atlantic (A.S. Gale collection, unregistered). C-D. Benthopecten simplex (Perrier, 1881), Recent, in abactinal (C) and actinal (D) views, Rockall Trough, NE Atlantic (NHMUK EE 13563). E-F. Nearchaster aciculosus (Fisher, 1910), Recent, in abactinal (E) and actinal (F) views, NE Pacific (USNM, unregistered). Scale bars: A-B $=7 \mathrm{~mm}$; C-D $=6 \mathrm{~mm}$; E-F $=20 \mathrm{~mm}$. 


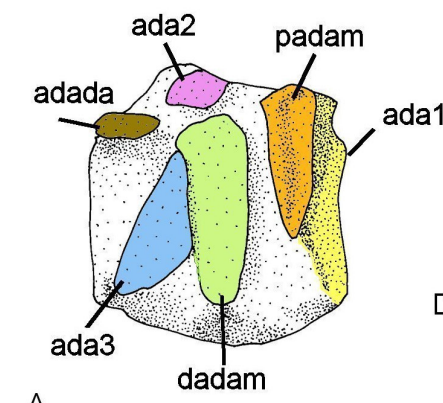

A

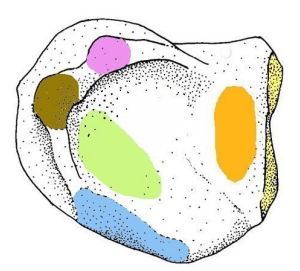

E
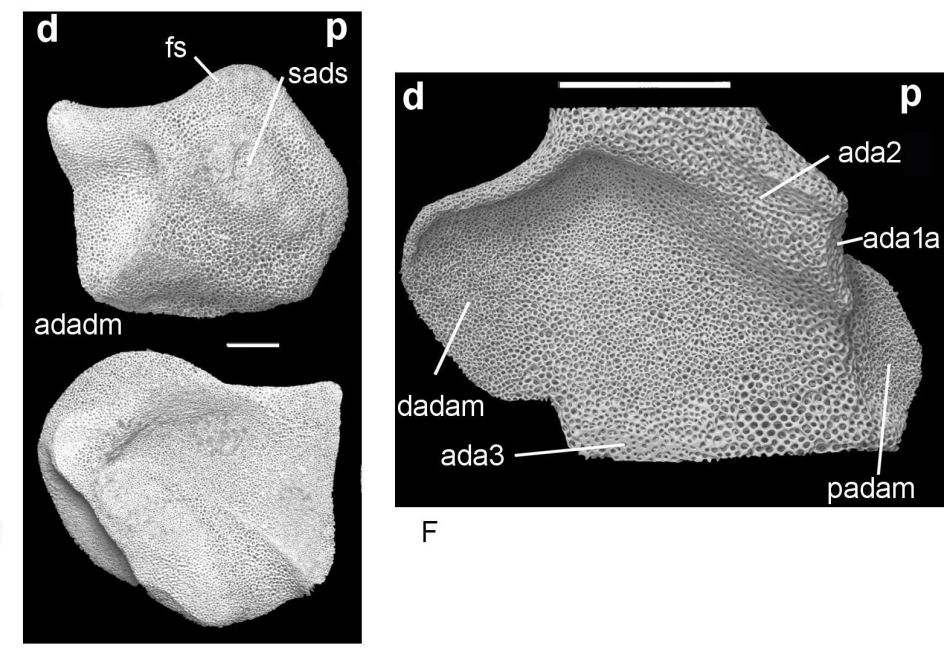

$\mathrm{F}$

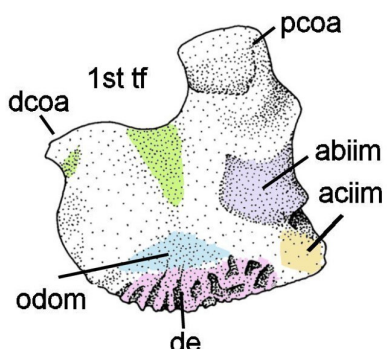

C

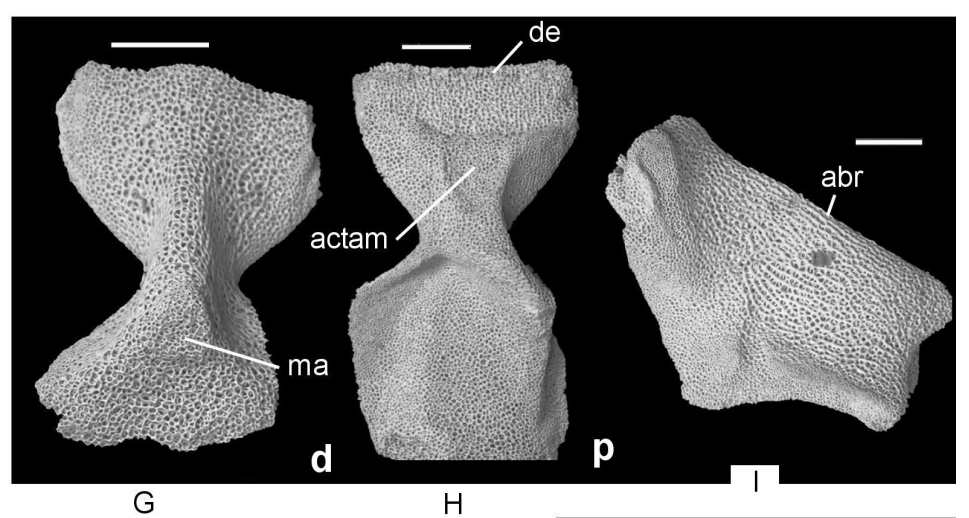

$\mathrm{H}$
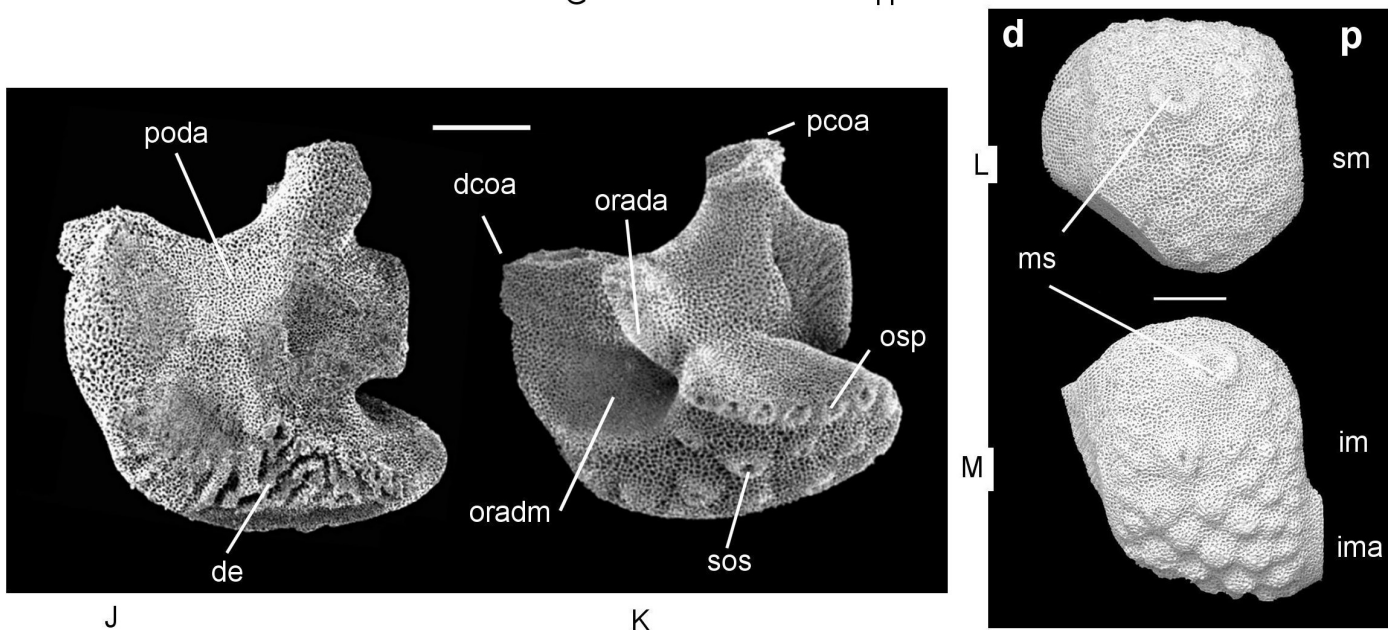

Fig. 3. A-C. Terminology used for adambulacrals and orals in the present paper. A. Actinal view of adambulacral of Luidia sp. - B-F. Benthopecten simplex (Perrier, 1881), Recent (NHMUK EE 13563). B. Abactinal view of adambulacral. C. Interradial view of oral ossicle. D-E. Adambulacral in actinal (D) and abactinal (E) views. F. Base of ambulacral in actinal view. - G-I. Cheiraster gazellae Studer, 1883, Recent (A.S. Gale collection, unregistered), ambulacral ossicles in abactinal (G), actinal (H) and proximal (I) views; note raised abactinal ridge (abr) and inferomarginal articulation (ma). J-M. Pontaster tenuispinus (von Düben \& Koren, 1846), Recent (A.S. Gale collection, unregistered). $\mathbf{J}-\mathbf{K}$. Oral ossicle in radial (K) and interradial (J) aspects. L-M. Supero- and inferomarginal pair. Abbreviations: $d=$ distal; $p=$ proximal; see Material and methods; after Gale 2011a: figs 10, 16. Scale bars: $1 \mathrm{~mm}$. 
- All but the few most proximal infero- and superomarginals alternate with each other (Fig. 4B-E).

- The articulation between successive inferomarginals is specialised. A flange is present on the proximal actinolateral surface of each inferomarginal, which carries a strip of smooth imperforate stereom for articulation with the distal part of the adjacent ossicle (Figs 3M, 4W).

- The ambulacrals are hourglass-shaped, with equally expanded triangular head and base (Fig. 5I-M). The ambulacral heads of successive ambulacrals abut, and do not imbricate.

- The ambulacral-adambulacral contact is highly modified (Blake 1973; Gale 2011a) in comparison to other paxillosidans (Fig. 3A-B). Articulation ada3 is elongated and positioned on the abradial margins of ambulacrals and adambulacrals (Fig. 3B, F). Adada and $\boldsymbol{a d a 2}$ are set on a raised ridge on the adambulacrals and the $\boldsymbol{a d a} \mathbf{2}$ articulation surface is present on a ridge on the ambulacral base (Fig. 3F). The central part of the ambulacral base adjacent is concave and sites of attachment of the ambulacraladambulacral muscles (padam, dadam) are strongly asymmetrical, with a reduced padam (Fig. 3F). The muscle attachment site padam is carried on short, wing-like flanges on the ambulacral bases. No other asteroids have this complex and highly derived ambulacral-adambulacral contact (Gale 2011a).

- The adambulacral construction and spination. The adradial margin of the ambulacrals projects into the groove, with an angled or rounded margin which carries a row of numerous adambulacral furrow spines. The central portion of the actinal adambulacral surface bears one or two large subadambulacral spines.

- The morphology and spination of the oral ossicles (Fig. 3C, J-K). The oral ossicles are trapezoidal in outline, with a convex actinal margin which carries a fringe of suboral spines. The inner face of the oral ossicles has dentition on the actinal border only.

- The presence of parapaxillae: distinctively modified abactinal ossicles. Although these are diverse in form, they have a common structure - a broad flat, rounded base, with a bevelled rim, and a raised central region which carries a centrally placed spine base, commonly surrounded by smaller spine bases (Fig. 4X-Z). Parapaxillae are unique to benthopectinids.

- Enlarged abactinal and marginal spines, when present, have a distinctive construction, being cylindrical, tapering, with a concavity on the base for articulation with the underlying ossicle. They are made up of thorny stereom similar in form to the verticillate structure in echinoid spines.

- The odontophore is shield-shaped and flattened, and the surfaces articulating with the oral ossicles extend along the length of the plate. This is unlike the odontophore of any other asteroids (Gale 2011a).

Fig. 4 (next page). A, D, J-M, O-P, S-W, Z. Pontaster tenuispinus (von Düben \& Koren, 1846), Recent (A.S. Gale collection, unregistered). A. Denuded radius, abactinal view. D. Lateral view of denuded arm. J-M. Superomarginals, lateral view. O-P, S, W. Inferomarginals, in lateral (O-P, S) and proximal (W) views. T. Circumoral ossicle. U-V. Oral ossicle. Z. Abactinal ossicle. - B, N, R, X. Nearchaster aciculosus (Fisher, 1910), Recent (A.S. Gale collection, unregistered). B. Lateral view of denuded arm. N, R. Marginal pair. X. Abactinal ossicle. - C, F-G, Y. Pectinaster filholi (Perrier, 1885), Recent (A.S. Gale collection, unregistered). C. Denuded arm, in lateral view. F-G. Marginal pair. Y. Abactinal ossicle. — E, Q. Cheiraster gazellae Studer, 1883, Recent (A.S. Gale collection, unregistered). E. Lateral view of denuded arm. Q. Lateral view of superomarginal. - H-I. Benthopecten simplex (Perrier, 1881), Recent (A.S. Gale collection, unregistered), lateral view of supero-/inferomarginal pair. Abbreviation: $\mathrm{d}=$ distal. See Fig. 3 for detailed morphological terminology. Scale bars: $A-E=5 \mathrm{~mm} ; \mathrm{F}-\mathrm{W}=1 \mathrm{~mm}$; $\mathrm{X}-\mathrm{Z}=0.5 \mathrm{~mm}$. 


\section{GALE A.S. \& JAGT J.W.M., Fossil benthopectinids (Echinodermata, Asteroidea) reappraised}

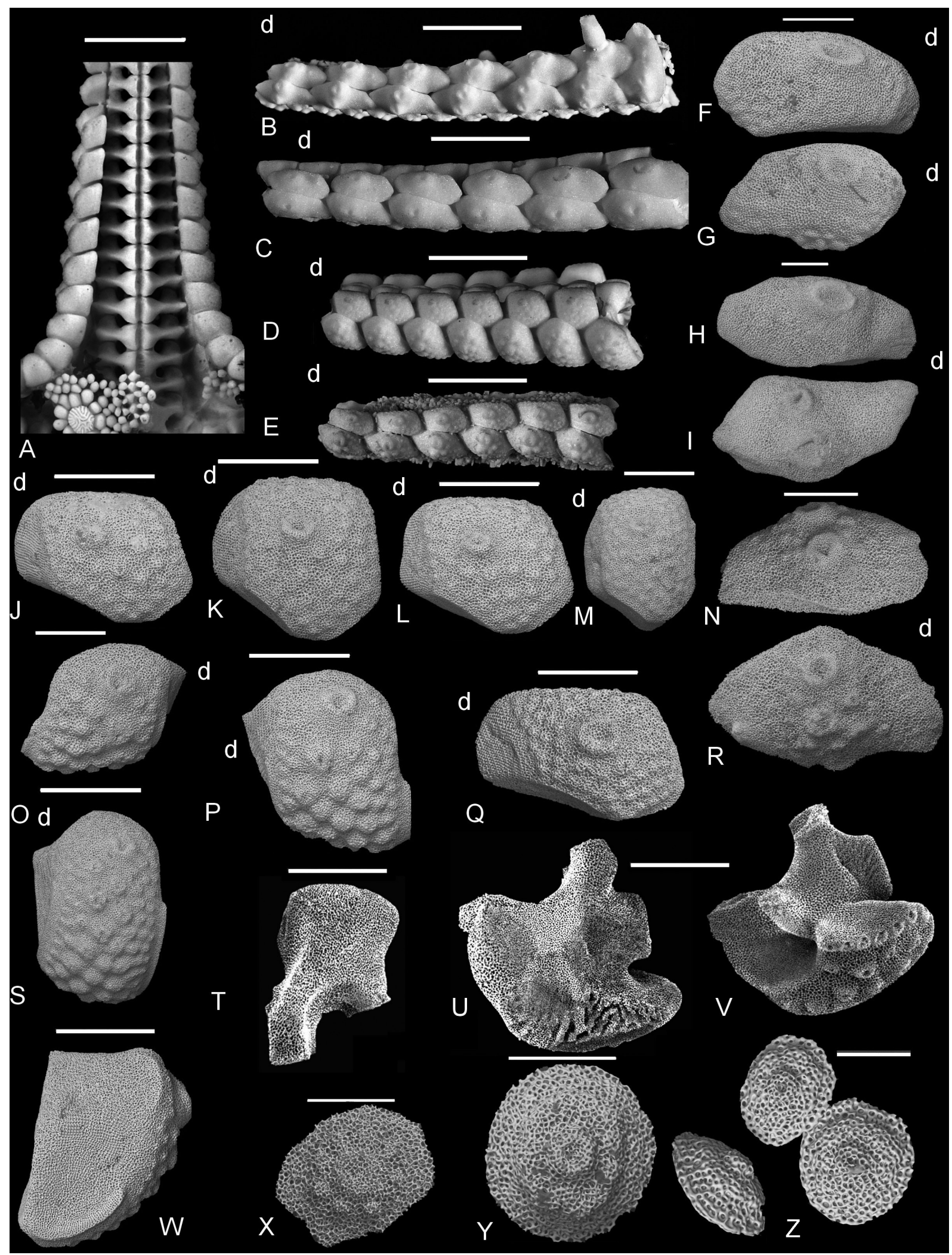


Table 1. Modern benthopectinids used for present study.

\begin{tabular}{lcc}
\hline \multicolumn{1}{c}{ Species } & Collection & Locality \\
\hline Pectinaster filholi Perrier, 1885 & IoS Southampton & Porcupine Trough, NE Atlantic \\
Pontaster tenuispinus (Duben \& Koren, 1846) & IoS Southampton & Porcupine Trough, NE Atlantic \\
Benthopecten simplex (Perrier, 1881) & IoS Southampton & Porcupine Trough, NE Atlantic \\
Nearchaster aciculosus (Fisher, 1910) & USNM & NE Pacific \\
Cheiraster gazellae Studer, 1883 & USNM & SW Pacific \\
\hline
\end{tabular}

The most recent revision of benthopectinids at the generic level was made by Clark (1981) and the Atlantic species of the family were thoroughly revised by Clark \& Downey (1992; see also Mah 2020a). There has been a long debate about both the number of extant benthopectinid genera, and the assignation of species to these genera. Clark (1981) summarised the taxonomic history of the family and provided a tabular key to benthopectinid taxa, of which she recognised eight genera and four subgenera. In the present study, additional characters were found to be of taxonomic value, most especially the shape, sculpture and articulation of the marginal ossicles.

\section{Morphological diversity of extant benthopectinids}

The morphology of five living benthopectinids is illustrated here with photographs of entire, dried specimens of Pontaster tenuispinus (Duben \& Koren, 1846), Cheiraster gazellae Studer, 1883 (Fig. 1), Pectinaster filholi Perrier, 1885, Benthopecten simplex (Perrier, 1881) and Nearchaster aciculosus (Fisher, 1910) (Fig. 2). The most conspicuous differences are the variable development of marginal spines; short and small in P. tenuispinus, larger and longer in the other taxa. Nearchaster aciculosus has elongated abactinal spines. The shape of the denuded marginal plates (Fig. 4B-E) is significantly different, as these are short and broad in Pontaster tenuispinus and Cheiraster gazellae (Fig. 4D-E) and elongated with a proximal and distal taper in Pectinaster filholi and Benthopecten simplex (Fig. 4B-C).

The skeletal morphology of five species of extant benthopectinids (Table 1) has also been examined, using bleach preparation and SEM examination of ossicle types (Figs 3-5), in order to make comparisons with fossil taxa.

Fig. 5 (next page). A, E, I-K. Cheiraster gazellae Studer, 1883 (A.S. Gale collection, unregistered). A, E. Adambulacral, in actinal and abactinal views, respectively. I-K. Ambulacrals, in abactinal, actinal and proximal views, respectively. - B, F, L-M. Pontaster tenuispinus (von Düben \& Koren, 1846) (A.S. Gale collection, unregistered). B, F. Adambulacral, in actinal and abactinal views, respectively. L-M. Ambulacral, in abactinal and actinal views, respectively. - C, G, P. Benthopecten simplex (Perrier, 1881) (A.S. Gale collection, unregistered). C, G. Actinal and abactinal views of adambulacral, respectively. P. Enlarged view of actinal surface of ambulacral base. - D, H, N. Nearchaster aciculosus (Fisher, 1910) (USNM, unregistered). D, H. Adambulacral in actinal and abactinal views, respectively. N. Enlarged view of actinal surface of ambulacral base. - O, Q-S. Pectinaster filholi (Perrier, 1885) (A.S. Gale collection, unregistered). O. Enlargement of ambulacral base, actinal view. Q. Proximal view of ambulacral. R-S. Abactinal and actinal views of adambulacral, respectively. Abbreviations: $d=$ distal; $\mathrm{p}=$ proximal. See Fig. 3 for detailed morphological terminology. Scale bars: A-N, P-S = $1 \mathrm{~mm}$; $\mathrm{O}=0.5 \mathrm{~mm}$. 


\section{GALE A.S. \& JAGT J.W.M., Fossil benthopectinids (Echinodermata, Asteroidea) reappraised}

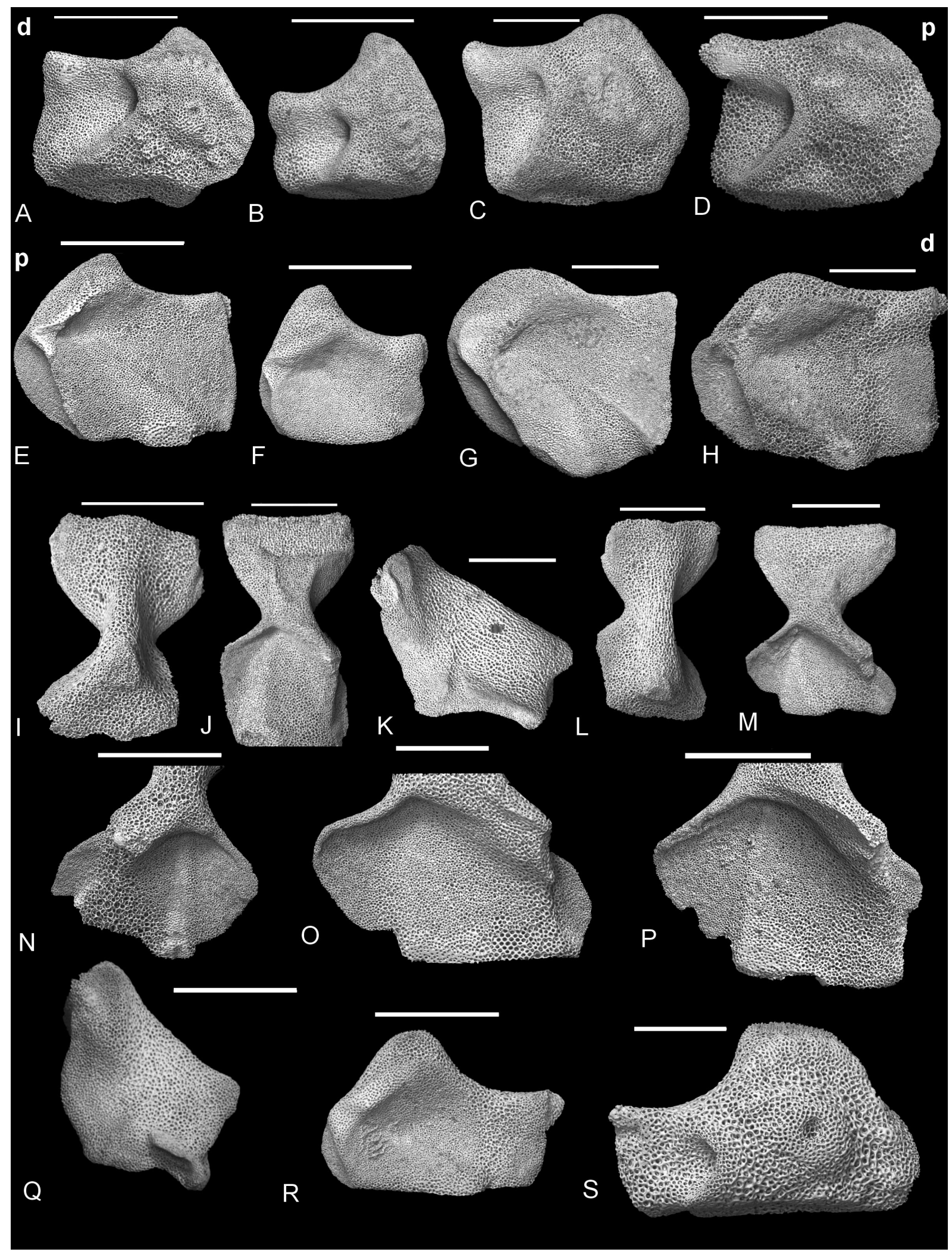




\title{
Phylogeny of the Benthopectinidae Verrill, 1894
}

The fossil material described in the present paper provides evidence of the timing and order of appearance of evolutionary novelties within the family. Firstly, the highly derived ambulacral-adambulacral articulation (see above) is ubiquitously present in all genera, and had evolved by the Lower Jurassic. Secondly, the abactinal ridges on the ambulacrals, and the presence of an articulation between the ambulacral base and the inferomarginals is a feature restricted to the crown group benthopectinids (all living taxa, plus their common ancestor) which did not appear until the Oligocene. The Mesozoic representatives of the family represent the stem group.

\author{
Phylum Echinodermata Bruguière, 1791 (ex Klein, 1734) \\ Class Asteroidea de Blainville, 1830 \\ Subclass Neoasteroidea Gale, 1987 \\ Order Paxillosida Perrier, 1884 \\ Family Benthopectinidae Verrill, 1894
}

Genus Nearchaster Fisher, 1911

Nearchaster Fisher, 1911: 91.

\section{Type species}

Acantharchaster aciculosus Fisher, 1910, by original designation.

Nearchaster spinosus (Blake, 1973) comb. nov.

Mistia spinosa Blake, 1973: 48, pl. 16 figs 30-44, pl. 17 figs 1-21, 35-36.

Brisingid (?) - Zullo et al. 1964: 334.

\section{Material examined}

UCMP A-5018 (holotype no. 10675) is the type and only specimen; it exposes a partly disarticulated abactinal surface showing the disc and proximal portions of four arms. Large marginal spines and smaller abactinal ones are visible. Marginals, adambulacrals, ambulacrals and abactinal ossicles of the holotype were figured individually by Blake (1973).

\section{Occurrence}

Keasey Formation (Lower Oligocene) near Mist, Oregon (USA).

\section{Description}

The abactinal surface of UCMP A-5018, embedded in matrix (Blake 1973: pl.16 fig. 44), shows part of the disc and four proximal arms. Although the outline is retained, the ossicles are jumbled and largely dissociated, such that adambulacrals and ambulacrals are visible on the actinal surface. The marginal spines, largely in place, are elongated and tapering. The abactinal spines are much smaller, perhaps one-fifth the size of those on the marginals. The adambulacrals are well preserved, subrectangular, with 2-3 large subadambulacral spine bases, and the concave inner (abactinal) surface and ridge bearing $\boldsymbol{a d a} \mathbf{2}$ and $\boldsymbol{a d a} 3$, characteristic of benthopectinids. The ambulacrals have the typical hourglass shape of benthopectinids, and asymmetry of the interambulacral muscles (P1 small, P2 large) is seen. The marginals are longer than broad with a convex, mound-like outer surface which carries 1-2 large spine bases and a number of sparsely scattered smaller ones. The inner surface of the marginals is flat. The abactinal ossicles are parapaxillae, with centrally placed, single spine bases, surrounded by a ring of smaller spines. 
GALE A.S. \& JAGT J.W.M., Fossil benthopectinids (Echinodermata, Asteroidea) reappraised

\section{Remarks}

As recognised by Blake (1973), the distinctive characters of the ambulacral, adambulacral and marginal ossicles place this form firmly in the Benthopectinidae. Comparison with extant benthopectinid species studied here indicates that Mistia spinosa shares important characters with the Recent Pacific genus Nearchaster, including the following:

1. Adambulacrals are nearly identical in shape to those of Nearchaster aciculosus, and both carry 2-3 bases for subambulacral spines.

2. Marginals are closely similar to those of N. aciculosus in both shape and distribution of spine bases.

The overall form of the body, with large marginal spines, and shorter abactinal spines on the disc is broadly similar to the development in the genera Benthopecten, Nearchaster and Myonotus Fisher, 1911 (see Fisher 1911: pls 22-26). The proportionate sizes and distributions of spines in Mistia spinosa are closest to those in Benthopecten claviger Fisher, 1910, Myonotus intermedius (Fisher, 1910) and Nearchaster aciculosus (Fisher, 1910) (see Fig. 2E-F herein).

The abactinal parapaxillae of Mistia spinosa are very close in structure to those of N. aciculosus, with a central spine base surrounded by a ring of smaller ones.

In conclusion, Mistia spinosa is a benthopectinid which has remarkably detailed similarities of ossicle morphology to the present-day Pacific species Nearchaster aciculosus and it is therefore provisionally placed in that genus. The genus thus has a history in the Pacific Ocean of at least 33 million years.

Genus Jurapecten Gale, 2011

Jurapecten Gale, 2011a: 84, pl. 19.

\section{Type species}

Jurapecten hessi Gale, 2011, by original designation.

\section{Diagnosis}

Benthopectinids which possess strongly rugose marginals; rugosities conjoined by thin radiating strips of imperforate stereom; ambulacrals lack abactinal ridges and inferomarginal articulation.

\section{Assigned species}

In addition to the type species, $J$. infrajurensis sp. nov. and $J$. dhondtae sp. nov., both described below.

\section{Remarks}

Jurassic-Cretaceous benthopectinids are locally common among isolated ossicles in washed residues. All share the same distinctive sculpture type of prominent imperforate rugosities, conjoined by radiating strips of stereom (e.g., Figs $6 \mathrm{~N}-\mathrm{O}, 7 \mathrm{G}, \mathrm{I}-\mathrm{J}$ ), absent on extant genera. In the extant genera Pontaster and Cheiraster, the rugosities on the superomarginals are smaller and more widely spaced (e.g., Fig. 4J-M, Q), although the inferomarginal sculpture is similar to that seen in Jurapecten (Fig. 6C-E). Jurapecten also lacks a number of characters seen in all extant taxa, including an abactinal ridge on the ambulacrals (compare Fig. $7 \mathrm{~N}-\mathrm{O}$ with Fig. 5I, K-L, Q), and there is no ambulacral articulation surface with the inferomarginal (compare Fig. 7N-O with Fig. 5I, K, Q). Additionally, the ambulacral heads are more elongated in Jurapecten (e.g., Figs 6J, L, 8Q-U). The absence of the abactinal ridge, to which the longitudinal arm muscles attach in all living genera (Clark 1981), is a plesiomorphic feature of Jurapecten. 
Jurapecten hessi Gale, 2011

Figs $6 \mathrm{C}, \mathrm{G}, 7 \mathrm{~K}-\mathrm{Y}$

Jurapecten hessi Gale, 2011a: 84, pl. 19 figs 1-6, 8-12, pl. 20 figs 6-10, 12-14, 19.

Jurapecten hessi-Gale 2011b: 76, fig. 6a-h.

\section{Diagnosis}

Jurapecten in which the marginals bear a sculpture of discrete, rounded rugosities and 1-3 larger spine bases on inferomarginals. Ambulacral base short.

\section{Material examined}

The type specimen, NHMUK EE 13594, consists of a set of associated ossicles from the upper Oxfordian (Couches d'Effingen, bifurcatus ammonite Zone, stenocycloides ammonite Subzone) at Savigna, near Orgelet (Département du Jura, France; see Gale 2011a, 2011b). Additional material comprises several hundred ossicles and groups of associated ossicles from the type locality (NHMUK collections).

\section{Remarks}

There is little new information or material since the original description by Gale (2011a, 2011b); differences with $J$. infrajurensis sp. nov. are discussed under that species (see below).

Jurapecten infrajurensis sp. nov. urn:lsid:zoobank.org:act:203C99CB-ECC0-4663-B650-853B9085C0F0

Figs 6I-U, 7A-J

\section{Diagnosis}

Jurapecten in which the ambulacral base broadens abradially; sculpture of superomarginals comprises a reticulum of conjoined rugosities.

Fig. 6 (next page). A-B, F. ? Benthopectinidae. A-B. Inferomarginals, in lateral aspect (MHI 2183/7, MHI 2183/8). F. Oral ossicle in radial view (MHI 2183/9). - C, G. Jurapecten hessi Gale, 2011. C. Inferomarginal, in lateral view (NHMUK PI EE 17988). G. Oral ossicle, in radial view (NHMUK EE 13606; the original of Gale 2011a: pl. 20 fig. 10). - D-E, H. Pontaster tenuispinus (von Düben \& Koren, 1846). D-E. Lateral view of inferomarginals. H. Oral ossicle (A.S. Gale collection, unregistered). - I-U. Jurapecten infrajurensis sp. nov. I. Oral ossicle, radial view (SNSB-BGSP2020XLV 31). J-M. Ambulacral ossicles, in actinal views ( $\mathrm{J}=$ holotype, NHMUK PI EE 17989; K-L = paratypes, NHMUK PI EE 17990-17991; M = SNSB-BGSP2020XLV16). N-O. Marginal ossicles (paratypes, NHMUK PI EE 17992-17993). P, R-T. Adambulacral ossicles (paratypes), in actinal (P, R) and abactinal (S-T) views (R-S = NHMUK PI EE 17994-17995; P, T = SNSB-BGSP2020XLV 17, SNSBBGSP2020XLV 19). I, Q. Oral ossicles, in radial view (paratypes: SNSB-BGSP2020XLV 15, SNSBBGSP2020XLV 18). U. Circumoral ossicle (paratype: SNSB-BGSP2020XLV 20). Provenance: A-B, F. Maantang Formation (Carnian, Upper Triassic), sample C30, Jiancougou, Sechuan Province, China. C, G. Upper Oxfordian (Couches d'Effingen, bifurcatus ammonite Zone, stenocycloides ammonite Subzone), Savigna, near Orgelet, Département du Jura, France (Gale 2011b). D-E, H. Recent, Porcupine Trough, NE Atlantic. I, M, P-Q, T-U. Upper Toarcian-lower Aalenian (possibly aalensis ammonite Zone), Quedlinburg (Landkreis Harz, northern Germany; Hess 2014). J-L, N-O, R-S. Middle Toarcian, Le Clapier (Département d'Aveyron), 62 km WNW of Montpellier, southern France (Thuy 2012). See Fig. 3 for detailed morphological terminology. Scale bars: A-H $=0.4 \mathrm{~mm}$; $\mathrm{I}-\mathrm{U}=0.2 \mathrm{~mm}$. 


\section{GALE A.S. \& JAGT J.W.M., Fossil benthopectinids (Echinodermata, Asteroidea) reappraised}

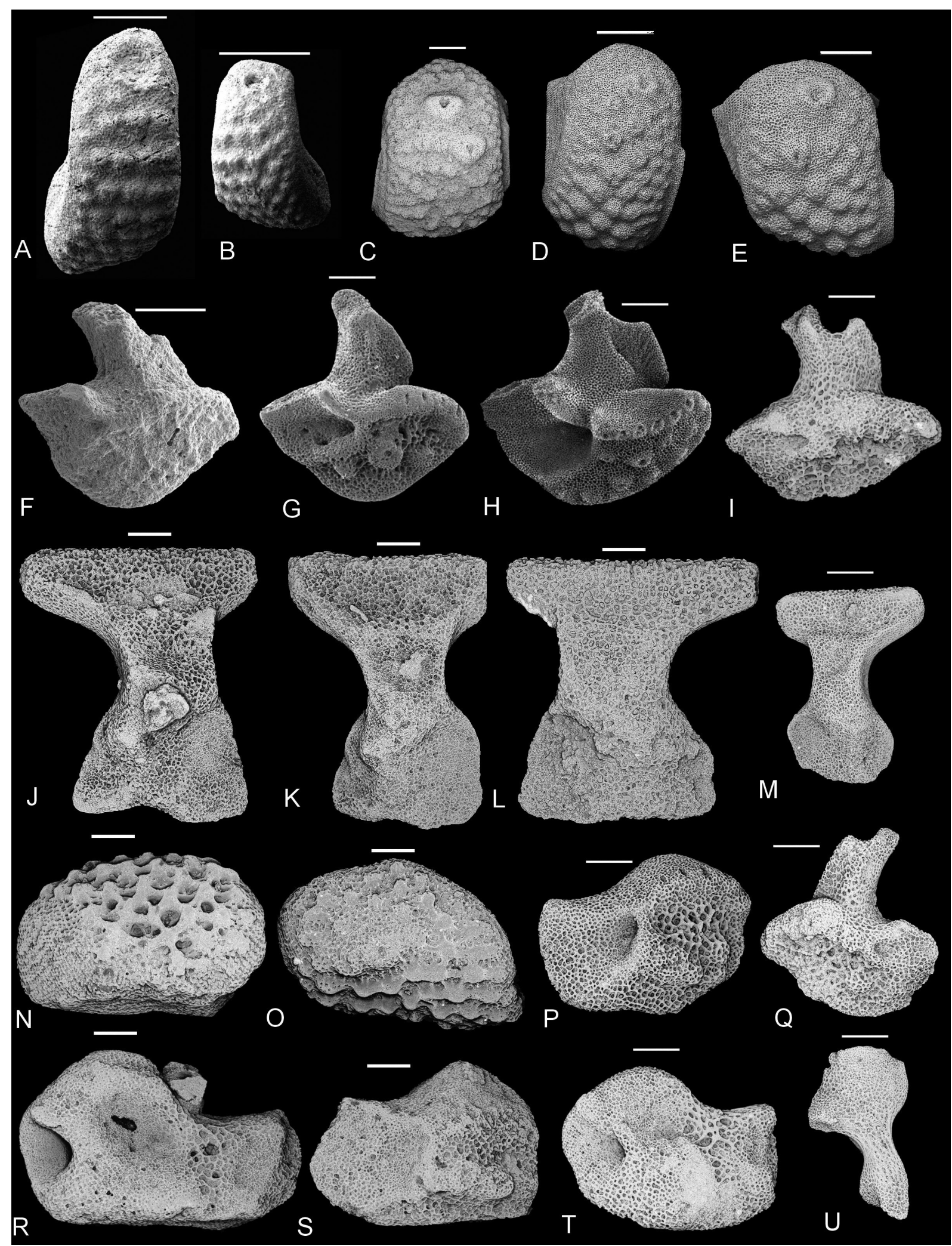




\section{Etymology}

From the Latin 'infra', in allusion to the occurrence of the species in the Lower Jurassic.

\section{Material examined}

The ambulacral illustrated here (Fig. 6J) is the holotype (NHMUK PI EE 17989); paratypes are NHMUK PI EE 17990-17995. All specimens are from middle Toarcian strata at Le Clapier (Département d'Aveyron, 62 km WNW of Montpellier, southern France; see Thuy 2012). Additional paratypes are fifteen ossicles (SNSB-BGSP 2020 XLV 16-30) from the upper Toarcian-lower Aalenian (possibly aalensis ammonite Zone) at Quedlinburg (Landkreis Harz, northern Germany; see Hess 2014).

\section{Description}

Marginals block-like, length slightly exceeding height, carrying a sculpture of rugosities, on inferomarginals aligned into transverse rows parallel with arm (Figs 6O, 7I). On proximal superomarginals (Fig. 7C-D) rugosities discrete and centrally placed single spine base present; on distal superomarginals rugosities conjoined by narrow radial struts, forming a reticulum of imperforate stereom (e.g., Figs $6 \mathrm{~N}$, 7G). Ambulacrals (Figs 6J-M, 7A, H) waisted, with elongated heads and broad flat bases; abactinal ridge absent (Fig. 7A). Bases with broad padam site, slightly shorter than dadam (Fig. 6J-L). Adambulacrals (Figs 6P, R-T, 7B, E-F) with deep adadm site, distally placed padam and broad ada1 (best seen in Fig. 6R); ada3 diffuse. Orals (Fig. 6I, Q) with tall, distally recurved apo, concave actinal face, low, lozenge-shaped body. Circumoral (Fig. 6U) with elongated poda, short doda.

\section{Remarks}

Jurapecten infrajurensis sp. nov. differs from $J$. hessi (see above) in the more elongated ambulacral base, and the more coarsely rugose sculpture of both infero- and superomarginals, which lack enlarged spine pits.

Fig. 7 (next page). A-J. Jurapecten infrajurensis sp. nov., various ossicle types (paratypes). A, H. Ambulacrals, in lateral and actinal aspects, respectively (SNSB-BGSP2020XLV 21,SNSBBGSP2020XLV 28). B, E-F. Adambulacrals, in actinal and abactinal views (SNSB-BGSP2020XLV 22, SNSB-BGSP2020XLV 25-26). C, G, J. Superomarginals, in lateral views (SNSB-BGSP2020XLV 23, SNSB-BGSP2020XLV 27, SNSB-BGSP2020XLV 30). D, I. Inferomarginals, in lateral views (SNSB-BGSP2020XLV 24, SNSB-BGSP2020XLV 29). - K-Y. Jurapecten hessi Gale, 2011. K, P, U. Adambulacral ossicles. K. Abactinal view (NHMUK PI EE 17996). P. NHMUK EE 13598 (the original of Gale 2011a: pl. 19 fig. 11). U. NHMUK EE 13599, the original of Gale (2011a: pl. 20 fig. 12). L. Circumoral ossicle (NHMUK EE 13605, the original of Gale 2011a: pl. 20 fig. 13). M-N. Ambulacral ossicles, in actinal and abactinal views, respectively (NHMUK EE 13595-13596, the originals of Gale 2011a: pl. 19 figs 8-9). O. Ambulacral, in proximal/distal view (NHMUK 13597). Q-S. Superomarginal ossicles (NHMUK EE 13601-13602; the originals of Gale 2011a: pl. 20 figs 6-7). T, V-W. Inferomarginals (NHMUK EE 13600, EE 13603-13604, EE 13608, the originals of Gale 2011a: pl. 20 figs 5, 8, 16). X-Y. Oral ossicles (NHMUK EE 1360613607, the originals of Gale 2011a: pl. 20 figs 10, 14). Provenance: A-J. Upper Toarcian-lower Aalenian (possibly aalensis ammonite Zone), Quedlinburg (Landkreis Harz, northern Germany; see Hess 2014). K-Y. Upper Oxfordian (Couches d'Effingen, bifurcatus ammonite Zone, stenocycloides ammonite Subzone), Savigna, near Orgelet, Département du Jura, France (Gale 2011b). Abbreviations: d = distal; $\mathrm{p}=$ proximal. See Fig. 3 for detailed morphological terminology. Scale bars: A-J $=0.2 \mathrm{~mm}$; $-\mathrm{Y}=$ $0.5 \mathrm{~mm}$. 


\section{GALE A.S. \& JAGT J.W.M., Fossil benthopectinids (Echinodermata, Asteroidea) reappraised}

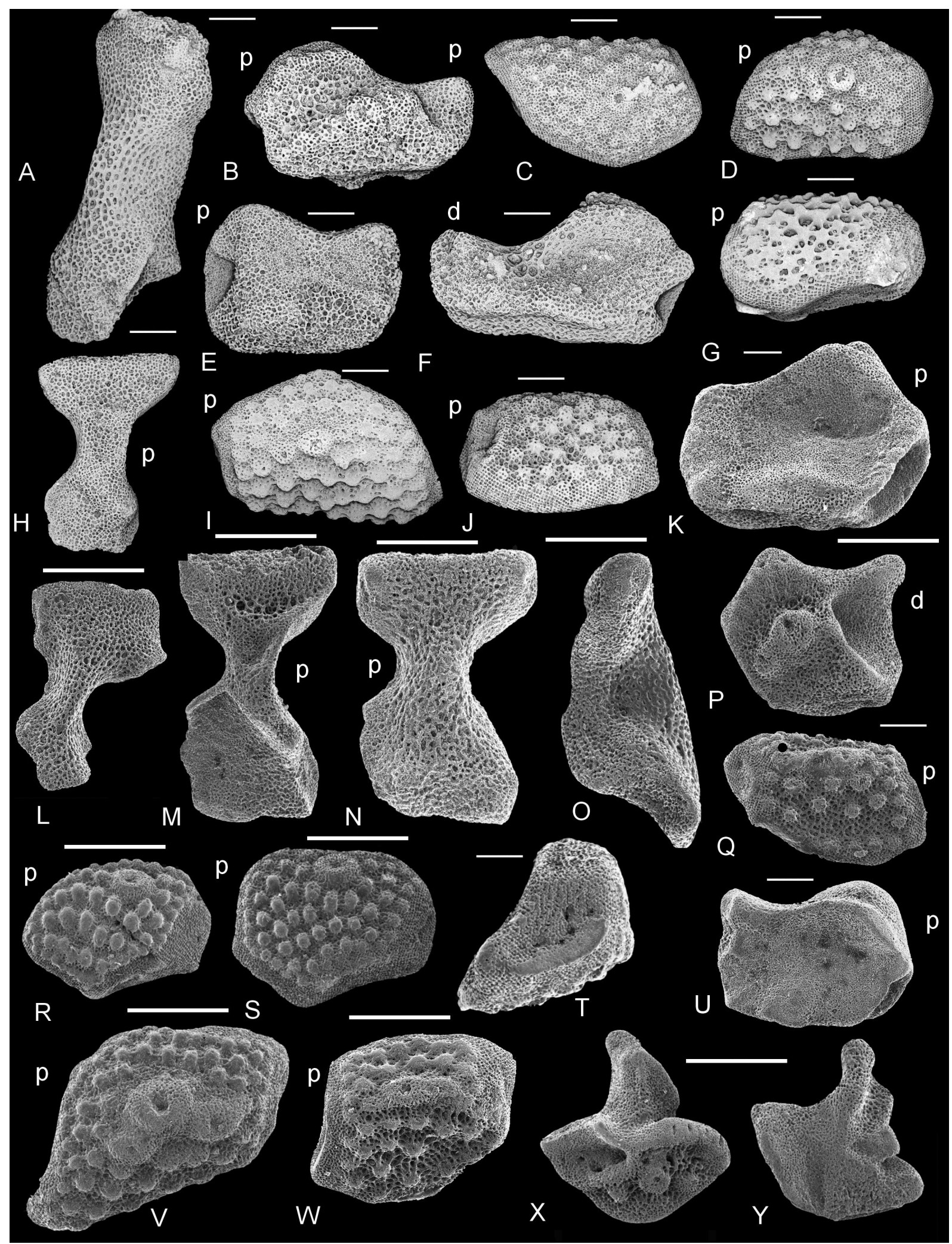


Jurapecten dhondtae sp. nov.

urn:1sid:zoobank.org:act:3CEF9EA0-184A-4352-87FA-CC5F76FED11A

Fig. $8 \mathrm{~A}-\mathrm{H}, \mathrm{J}-\mathrm{V}$

benthopectinid sp. 1 (? spp.) - Jagt 2000: 393, pl. 6 figs 1-4.

Cheiraster? sp. - Blake \& Jagt 2005: 190, pl. 5 figs 1-7.

\section{Diagnosis}

Jurapecten in which the marginal ossicles possess a coarsely rugose sculpture and the inferomarginals bear a single, large, laterally directed spine base.

\section{Etymology}

Named after Annie V. Dhondt (1942-2006), specialist of Cretaceous bivalves and close friend.

\section{Material examined}

The inferomarginal illustrated here (Fig. 8F) is the holotype (NHMM JJ 10490a), while the other figured ossicles in lot NHMM JJ 10490 are paratypes. Additional material includes around 50 isolated ossicles (lot NHMM JJ 9591). All material is from the upper Maastrichtian (Maastricht Formation, Emael Member, Lava Horizon) at the CBR-Romontbos Quarry, Eben Emael (Liège, northeast Belgium).

\section{Description}

Superomarginals (Fig. 8A-D) block-like, nearly equidimensional, elongating distally. Outer face with sculpture of dense rugosities of similar size and single, crater-rimmed spine base positioned towards abactinal-distal margin. Inferomarginals (Fig. 8E-H, J-K) asymmetrical, proximal margins broader than distal margins; inter-inferomarginal articulation facet close to actinal surface of plate (Fig. 8J), forming short projection. External face of inferomarginal with sculpture of coarse, rounded rugosities and single, large crater-rimmed spine base, positioned centrally, or slightly towards abactinal margin. Ambulacrals (Fig. 8Q-V) with elongated, bar-like $\boldsymbol{a} \boldsymbol{m} \boldsymbol{b} \boldsymbol{h}$, broad, flat $\boldsymbol{a} \boldsymbol{m} \boldsymbol{b} \boldsymbol{b}$, with large, flat surface for dadam and ada3, padam on short wing. Abactinal ridge and inferomarginal articulation absent (Fig. 8V). Adambulacrals (Fig. 8L-M) with concave abactinal face, actinal face with single subambulacral spine base. Enlargement of dadam (Fig. 8P) shows irregularly ridged region, similar to that seen on extant Pectinaster filholi (Perrier, 1885) (Fig. 8I).

\section{Remarks}

The marginal ossicles (Fig. 8A-H, J-K) are closely similar to those of Pontaster tenuispinus (von Düben \& Koren, 1846) (compare with Fig. 4J-M, O-Q) in shape, sculpture and spine base development,

Fig. 8 (next page). A-H, J-V. Jurapecten dhondtae sp. nov. A-D. Superomarginals in lateral view (NHMM JJ 10490b-e). E-H, J-K. Inferomarginals (NHMM JJ 10490f-j), in lateral (E-H, K) and distal (J) views. E. Original of Jagt (2000: pl. 6 fig. 2; NHMM JJ 9591i). F. Holotype (NHMM JJ 10490a). L-P. Adambulacrals, in actinal $(\mathrm{M}-\mathrm{N})$ and abactinal $(\mathrm{L}, \mathrm{O})$ views, with $(\mathrm{P})$ enlargement to show ridges (lot NHMM JJ 9591). Q-V. Ambulacrals, in actinal (Q, S, U), abactinal (R, T) and proximal/distal (V) views (lot NHMM JJ 9591). - I. Pectinaster filholi (Perrier, 1885) (A.S. Gale collection, unregistered), enlargement of area on actinal surface of ambulacral. Provenance: A-H, J-V. Upper Maastrichtian, CBR Romontbos quarry, Eben Emael (Liège, NE Belgium), Maastricht Formation, Emael Member (Lava Horizon). I. Recent, Rockall Trough, northeast Atlantic. Abbreviations: $d=d i s t a l ; p=$ proximal. See Fig. 3 for detailed morphological terminology. Scale bars: A-H, J-O, Q-V = 1 mm; I, P = $0.2 \mathrm{~mm}$. 


\section{GALE A.S. \& JAGT J.W.M., Fossil benthopectinids (Echinodermata, Asteroidea) reappraised}
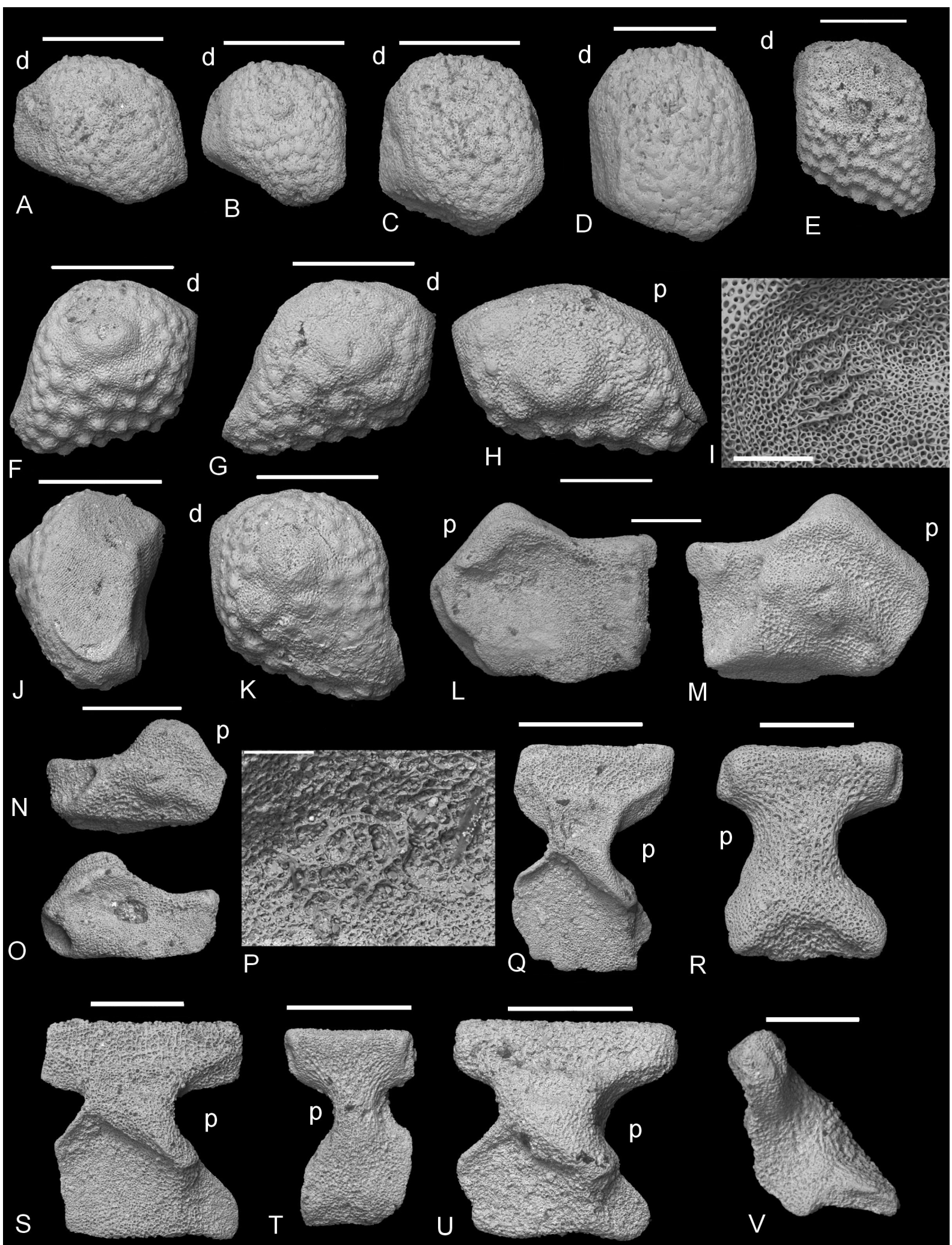
but the ambulacrals (Fig. 8Q-V) possess elongated heads and lack abactinal ridges and inferomarginal articulation structures, and compare better with those of Jurapecten hessi and J. infrajurensis sp. nov. (see Figs 6J-M, 7M-O).

The partially preserved specimen (NHMM MD 4105), described and illustrated by Blake \& Jagt (2005), may be conspecific, but recrystallisation of all ossicle types precludes detailed comparison of the sculpture of infero- and superomarginal ossicles and ambulacral ossicles are too poorly preserved. The type material of $J$. dhondtae sp. nov., from the middle Emael Member, is ca 200000 years younger than NHMM MD 4105, from the basal Gronsveld Member (compare Keutgen 2018).

Genus Punkaster gen. nov.

urn:Isid:zoobank.org:act:D63466E2-7CA4-4896-BFD2-4D156A280AA8

\section{Type species}

Punkaster spinifera gen. et sp. nov.

\section{Diagnosis}

Highly derived form in which the marginal ossicles are very elongated, proximal infero-and superomarginal pairs occasionally fused, and marginals may possess 1-2 large rounded bases for attachment of conical spines. Adambulacrals with deep rounded notch to allow extension of tube feet and very large furrow spines.

\section{Etymology}

From the similarity of the marginal spination to the 1980s punk hairdos.

\section{Assigned species}

In addition to the type species, $P$. ruegenensis gen. et sp. nov. (see below).

\section{Remarks}

The highly unusual marginal ossicles of this new genus (Fig. 9E, I-J, M, P) have been known for over 60 years, but they remained undescribed and it has hitherto not been possible to assign them to any family. The new material includes ambulacral and adambulacral ossicles, which demonstrate a likely affinity with benthopectinids in the elongated, bar-like ambulacral heads and, especially, in the nature of the ambulacral/adambulacral articulation. This is typically benthopectinid, in the abradial position of $\boldsymbol{a d a}$, the position of padam on a short wing-like process and the presence of $\boldsymbol{a d a} 2$ on a steep ridge. The abactinal ossicles are closely similar to parapaxillae of modern benthopectinids. The presence of an abactinal ridge on the ambulacrals of $P$. spinifera gen. et sp. nov. may indicate that the species possessed longitudinal muscles in the arms. The genus perhaps represents a highly specialised offshoot from the mainline benthopectinids.

Punkaster spinifera gen. et sp. nov. urn:lsid:zoobank.org:act:89D1989C-BB8C-459E-84D4-40874052C57C

Figs 9-11, 12J-K

Zwischenplatten QA, RA - Müller 1953: 45, pl. 10 figs qa-ra.

indeterminate "cryptozonid" - Jagt 1999: pl. 2 figs 1-2, 4.

benthopectinid sp. 2 - Jagt 2000: 394, pl. 6 figs 5-6, 8, 10-12, pl.7 figs 1-2. 
GALE A.S. \& JAGT J.W.M., Fossil benthopectinids (Echinodermata, Asteroidea) reappraised

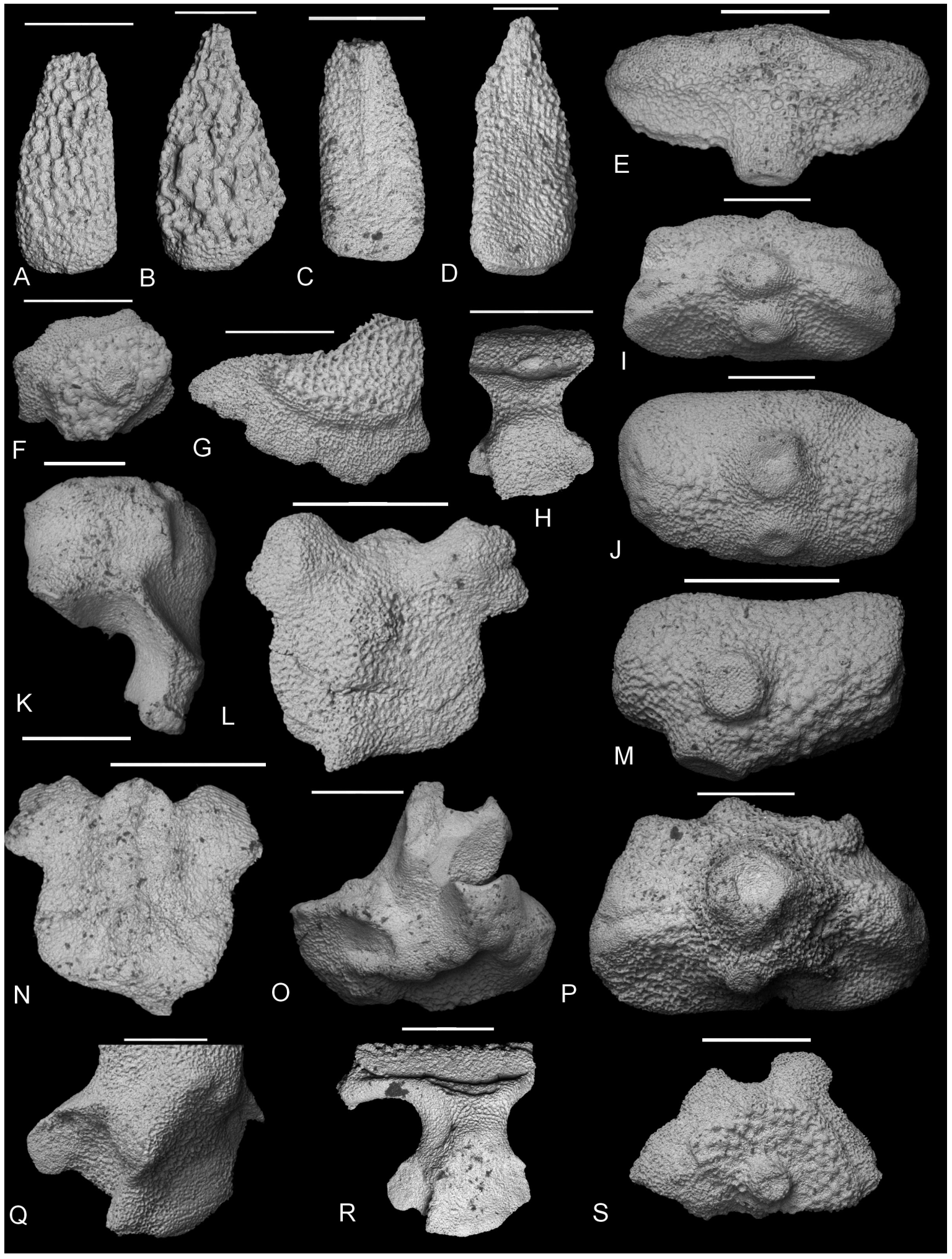

Fig. 9. Punkaster spinifera gen. et sp. nov. (holotype, NHMM JJ 11736). A-D. Subadambulacral or suboral spines. E, I-J, M, P. Marginal ossicles. F-G, S. Abactinal ossicles. H, Q-R. Ambulacrals, in actinal view. K. Circumoral, in actinal view. L, N. Odontophore, in abactinal and actinal views. O. Oral ossicle, in radial view. Provenance: uppermost Maastrichtian, ca $12 \mathrm{~m}$ below K/Pg boundary, Kulsti Rende, Stevns Klint, eastern Denmark. Scale bars: A-D = $5 \mathrm{~mm}$; E-S = $1 \mathrm{~mm}$. 


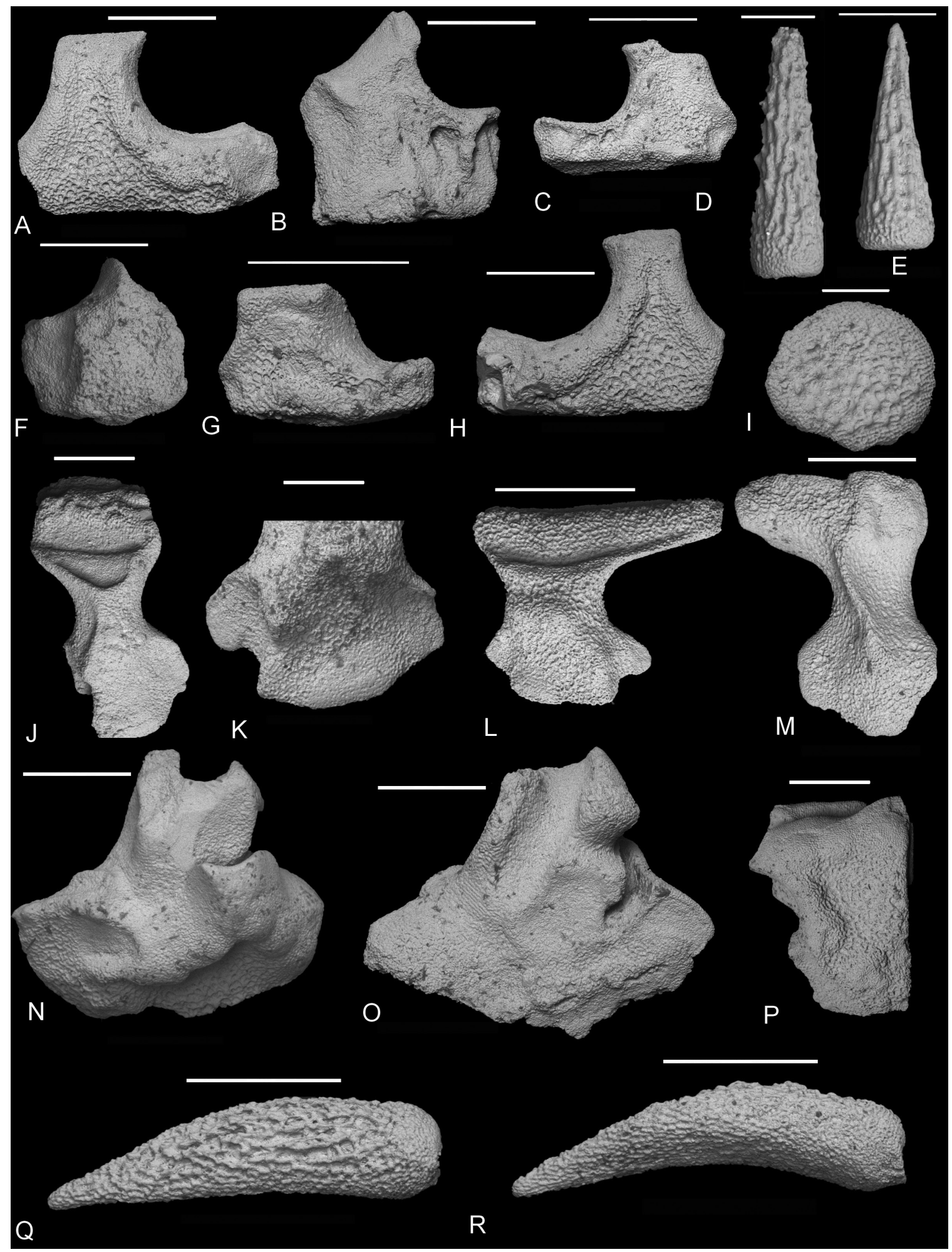

Fig. 10. Punkaster spinifera gen. et sp. nov. (holotype, NHMM JJ 11736). A-C, F-H. Adambulacral ossicles, in actinal $(\mathrm{A}, \mathrm{C}, \mathrm{H})$ and abactinal $(\mathrm{B}, \mathrm{F}-\mathrm{G})$ views. D-E. Abactinal or marginal spines. I. Abactinal ossicle. J-M. Ambulacral ossicles, in actinal (J-L) and abactinal (M) views. N-P. Oral ossicle, in radial $(\mathrm{N})$, interradial $(\mathrm{O})$ and actinal $(\mathrm{P})$ views. Q-R. Large spines of uncertain position. Provenance: uppermost Maastrichtian, ca $12 \mathrm{~m}$ below K/Pg boundary, Kulsti Rende, Stevns Klint, eastern Denmark. Scale bars: A-C, F-R $=1 \mathrm{~mm}$; D-E $=0.5 \mathrm{~mm}$. 
GALE A.S. \& JAGT J.W.M., Fossil benthopectinids (Echinodermata, Asteroidea) reappraised

\section{Diagnosis}

Punkaster gen. nov. in which the marginal ossicles carry 1-2 cylindrical spine bases, which bore conical spines.

\section{Etymology}

Derived from the Latin 'spinifera', meaning bearing spines.

\section{Material examined}

A set of $>100$ associated ossicles (marginals, a single terminal, abactinals, actinals, orals, circumorals, odontophores, adambulacrals, ambulacrals, marginal spines, adambulacral spines and oral spines) from ca 12 metres below the Cretaceous-Paleogene $(\mathrm{K} / \mathrm{Pg})$ boundary in the upper Maastrichtian Højerup Member (Tor Formation; Surlyk et al. 2006) at Kulsti Rende, Stevns Klint, eastern Denmark, is the holotype (NHMM JJ 11736). Additional material includes disarticulated, yet associated, ossicles of another individual from the same locality and stratigraphical unit, as well as isolated marginal ossicles from several localities exposing Cenomanian-Maastrichtian rocks in the United Kingdom (Kent, Hampshire), Belgium, Germany (Rügen, SNSB-BGSP collections; Aachen area) and the Czech Republic, including ossicles from the lower Campanian Chalk of Downend, Hampshire (Gale 1980).
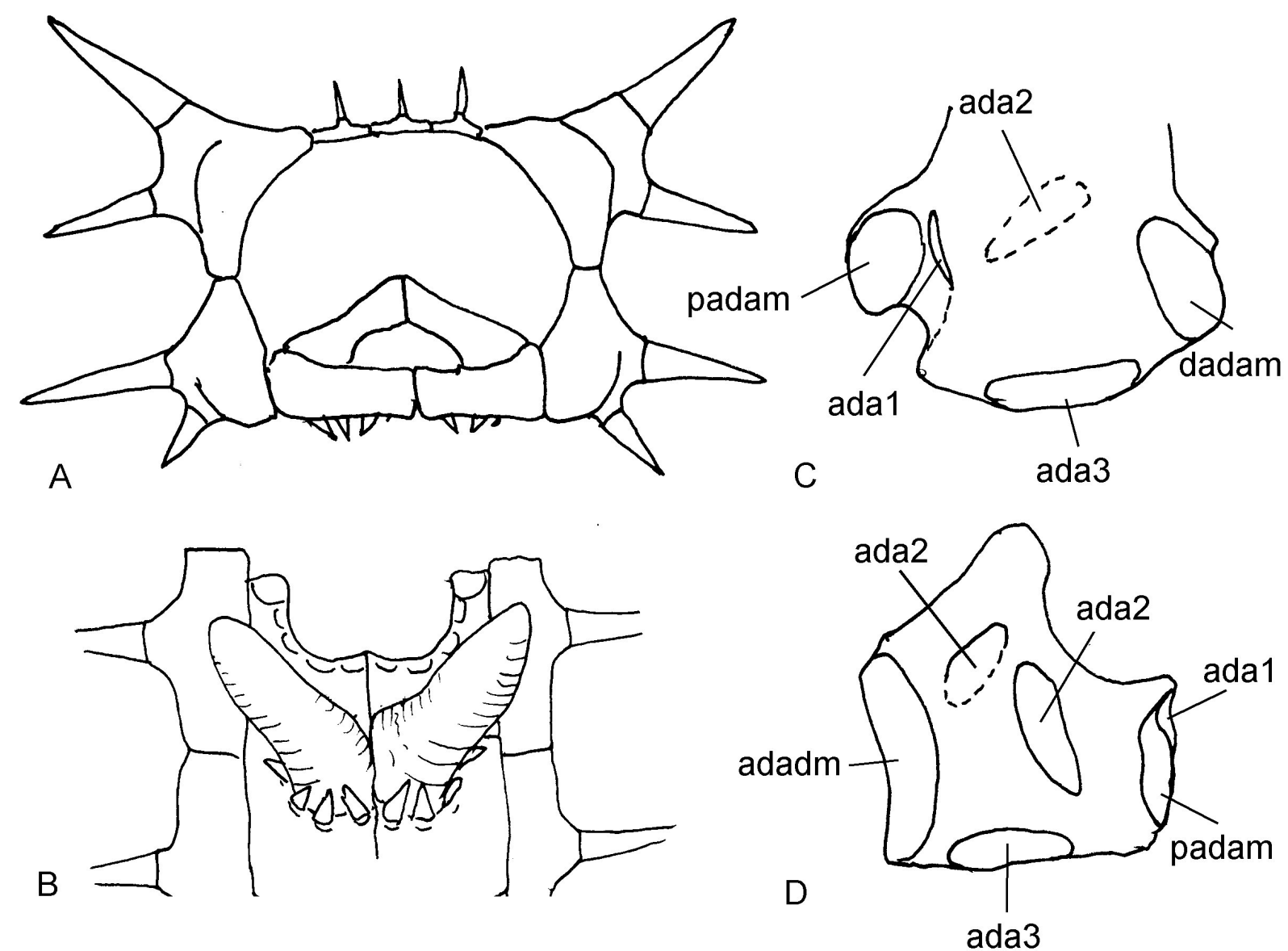

Fig. 11. Punkaster spinifera gen. et sp. nov., reconstructions and interpretation. A. Reconstruction of cross-section of arm. B. Reconstruction of ambulacral groove, with large podial basins and furrow spines. C. Ambulacral base, in actinal view. D. Abactinal face of adambulacral. Abbreviations: see Material and methods, and Fig. 3 for detailed morphological terminology. 


\section{Description}

Marginals are highly distinctive plates; supero- and inferomarginals elongated, broadly rectangular in lateral-abactinal aspect, with a length-parallel central rounded ridge, single oninferomarginals, bifurcating towards distal and proximal margins of superomarginals. Central, raised part of ridge carrying 2-3 spine bases, borne on cylindrical protrusions projecting from surface of ossicles. Superomarginals (Fig. 9E, I, P) with thin, narrow abactinal portion and opposing inferomarginals. Inferomarginals (Fig. 9J, M) with distinctive facet on internal surface for contact with adambulacrals. External surface of supero- and inferomarginals with complex sculpture comprising numerous small, rounded rugosities interconnected by network of stereom. Marginal spines (Fig. 10D-E) conical, thorny.

Adambulacrals boot-shaped in actinal and abactinal aspect, large adp forming heel, narrow distal extension (Fig. 10A, H); adradial margin deeply concave to accommodate large tube feet. Three to four attachment sites for $\boldsymbol{f} \boldsymbol{s}$, sads not present; probable $\boldsymbol{f} \boldsymbol{s}$ large, lanceolate (Fig. 9A-D). Abactinal surface (Fig. 11D) of adambulacrals showing ada3 on abradial margin, poorly defined ada2. Ambulacrals (Figs 9H, Q-R, 10J-M) in proximal position (Fig. 10J) short, broad, distal ambulacrals with elongated $\boldsymbol{a m b h}$ (Fig. 10L). Abactinal ridge present (Fig. 10M). Ambulacrals (Figs 9Q-R, 10K, 11C) with separate wing for padam, ada 3 on abradial margin, dadam large, ada 2 poorly defined, ada1 large. Oral ossicles robust, subtriangular, actinal surface trapezoidal, concave centrally (Fig. 10P). Proximal margin with three oral spine bases and two suboral spine bases on distal margin; apo stout, with shallow rng.

Abactinal ossicles flattened parapaxillae, with irregular lobed outlines and bevelled rim (Fig. 9F-G, S). Raised central area with finely rugose stereom which probably carried small spines. Some abactinals with single, outwardly directed spine base.

\section{Remarks}

Punkaster spinifer gen. et sp. nov. differs from P. ruegenensis gen. et sp. nov. (see below) in the unfused proximal supero- and inferomarginals and in the presence of large marginal spine bases. As seen in our reconstruction (Fig. 11), the marginals were paired, not alternating, and carried a transverse fan of 4-6 outwardly directed, large conical thorny spines (Fig. 11A). The species had very large tube feet, protected by large, lanceolate furrow spines (Fig. 11B).

Punkaster ruegenensis gen. et sp. nov. urn:1sid:zoobank.org:act:9762A572-434A-4D16-86F8-644D05201BC4

Fig. 12A-I, L-M

\section{Diagnosis}

Punkaster gen. nov. in which the proximal supero- and inferomarginals form fused pairs; distally, they are separate. Large marginal spine bases absent.

\section{Etymology}

Named after the island of Rügen (northeast Germany) in the Baltic Sea.

\section{Material studied}

The interradial marginal pair (Fig. 12A) is the holotype (SNSB-BGSP 2020 XLV 31); the other eight ossicles illustrated here are paratypes (SNSB-BGSP 2020 XLV 32-39), all from the upper lower Maastrichtian Chalk of Rügen, northeast Germany. Additional material includes over 30 marginal ossicles and other ossicles from the same locality (lot SNSB-BGSP 2020 XLV 32). 


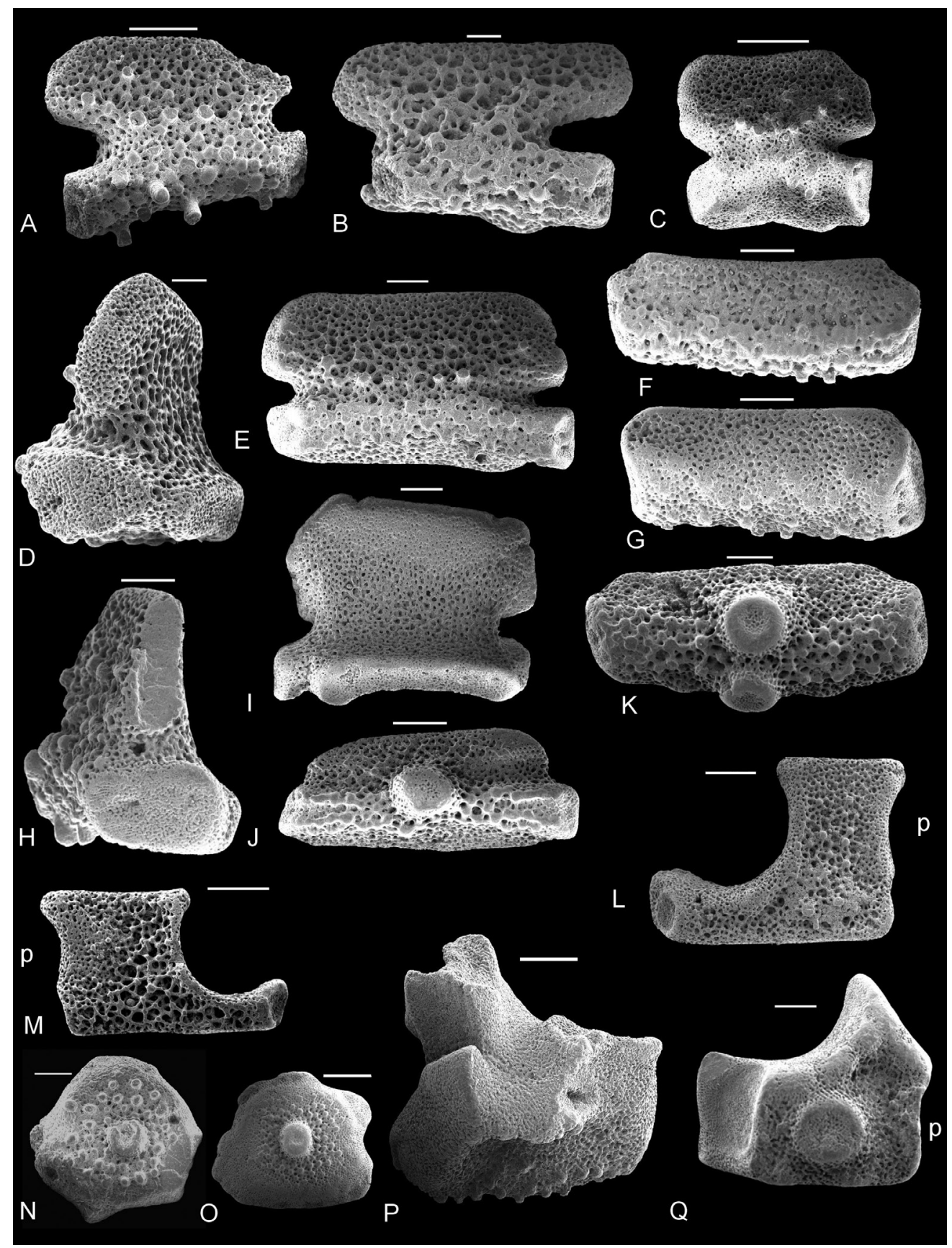

Fig. 12. A-I, L-M. Punkaster ruegenensis gen. et sp. nov. A-E, H-I. Fused marginal pairs, in lateral (A-C, E: SNSB-BGSP2020XLV 31-33, SNSB-BGSP2020XLV 35) views, at right angles to margin (D, H: SNSB-BGSP2020XLV 34, SNSB-BGSP2020XLV 38) views and internal view (I: SNSBBGSP2020XLV 39). F-G. Distal inferomarginals in lateral view (SNSB-BGSP2020XLV 36-37). A. Holotype (SNSB-BGSP2020XLV31). B-I. Paratypes (SNSB-BGSP2020XLV32-39). L-M. Probable adambulacrals, actinal view (lot SNSB-BGSP2020XLV 32). - J-K. Punkaster spinifera gen. et sp. nov., marginals (SNSB-BGSP2020XLV 40-41). - N-O. Punkaster gen. nov., sp. indet., abactinal ossicles (SNSB-BGSP2020XLV 42-43). - P. ? Punkaster gen. nov., sp. indet., oral ossicle, external view (SNSB-BGSP2020XLV 44). - Q. Punkaster gen. nov., sp. indet., adambulacral, actinal view (SNSB-BGSP2020XLV 45). All specimens are from the upper lower Maastrichtian of Rügen, NE Germany. Abbreviation: $p=$ proximal. See Fig. 3 for detailed morphological terminology. Scale bars: A, $\mathrm{C}-\mathrm{Q}=0.5 \mathrm{~mm} ; \mathrm{B}=0.2 \mathrm{~mm}$. 


\section{Description}

Proximal marginals fused, bilobed; actinal part formed by a low, elongated, concave inferomarginal, abactinal part a subrectangular flange, formed by superomarginal (Fig. 12A-E, H-I). Infero- and superomarginals separated by a notch of variable size. Proximal/distal profile L-shaped, articulation facets for adjacent marginal plates oval (Fig. 12D). External sculpture of coarse reticulate stereom network, with rugosities, and small cylindrical projections which carried spines. Distal inferomarginals (Fig. 12F-G) rectangular, elongated, with similar sculpture to proximal plates. Presumed adambulacral (Fig. 12L-M) boot-shaped, with deep podial notch and narrow distal portion. Large $\boldsymbol{f} \boldsymbol{s}$ bases present, central actinal face slightly inset, coarsely reticulate, rugose.

\section{Remarks}

The marginal ossicles are most unusual in that supero- and inferomarginal pairs are fused, perhaps uniquely amongst asteroids. The overall shape and sculpture of the ossicles suggest affinity with the type species, Punkaster spinifera gen. et sp. nov. (see above), but the present form differs in the fused proximal marginals and in the absence of large spine bases.

? Benthopectinidae Verrill, 1894

Fig. 6A-B, F

? Benthopectinidae Verrill, 1894: 217.

\section{Material}

Seventeen marginal ossicles; the inferomarginal figured(Fig. 6A) is MHI 2183/7; the other inferomarginal and oral ossicle illustrated here are MHI 2183/8 and 9. All are from the Maantang Formation (Carnian, Upper Triassic; sample C30) at Jiancougou, Sechuan Province, China.

\section{Description}

The inferomarginal and oral ossicles are strongly reminiscent in shape and external sculpture of those of benthopectinids; compare Fig. 6A-B with benthopectinid marginals (Fig. 6C-E), and the oral (Fig. 6F) with those of benthopectinids (Fig. 6G-I).

The inferomarginals share a number of similarities to those of benthopectinids (Fig. 6A-E), notably the coarse, longitudinally arranged rows of rugosities, the presence of a large spine (or pedicellaria) base close to the abactinal margin of the plate, and the marked asymmetry of the distal inferomarginals, in which the distal height is less than the proximal one. The oral ossicles (Fig. 6F) are remarkably similar to those of benthopectinids in the evenly convex actinal margin, the distally angled apophyse and the shape of the adambulacral articulation (Fig. 6G-I). However, the material available to date is too limited, and in the absence of ambulacrals and adambulacrals, this referral is very tentative.

Family Goniopectinidae Fisher, 1916

Genus Chrispaulia Gale, 2005

Chrispaulia Gale, 2005: 2, fig. 4a-c.

\section{Type species}

Nymphaster radiatus Spencer, 1905, by original designation (see Fig. 13A-C). 
GALE A.S. \& JAGT J.W.M., Fossil benthopectinids (Echinodermata, Asteroidea) reappraised

\section{Diagnosis}

Arms long, narrow; disc small, with rounded interbrachial arcs; superomarginals meeting over radius along length of arm; distal marginals imbricate (emended from Gale 2005).

\section{Assigned species}

In addition to the type species, Chrispaulia jurassica Gale, 2011 (Gale 2011a), C. wrightorum sp. nov. and C. spinosa sp. nov.

\section{Remarks}

The record in the Treatise of Invertebrate Paleontology (Part U; Spencer \& Wright 1966) of a benthopectinid from the "Albian of England" is based on an arm fragment from the Albian Red Chalk of Yorkshire, United Kingdom (C.W. Wright, pers. comm. to ASG, 1978). We have examined this specimen (NHMUK PI EE 17997), which comprises five marginal ossicles reconstructed on plasticene. The shape of the ossicles indicates that this specimen belongs to the genus Chrispaulia; it is here described as a new species, $C$. wrightorum sp. nov. (see below). In addition, we record another species from the Hauterivian (Lower Cretaceous) of northeast England and northern Germany.

Chrispaulia wrightorum sp. nov. urn:1sid:zoobank.org:act:DC13434F-62E3-47A9-9F62-327F77141670

Fig. $13 \mathrm{~F}-\mathrm{G}$

?Benthopecten sp. - Spencer \& Wright in Moore 1966: U48.

\section{Diagnosis}

Chrispaulia with smooth marginal ossicles, in which the distal superomarginals possess a single large spine pit close to their distal, abactinolateral border.

\section{Etymology}

After the late brothers C.W. and E.V. Wright, who collected the specimen.

\section{Material examined}

The arm fragment (NHMUK PI EE 17997) from the Albian Red Chalk (Hunstanton Formation) at Speeton, Yorkshire (United Kingdom) is the holotype and single specimen known to date. The specimen was originally articulated; it was subsequently reconstructed on plasticene by the Wright brothers.

\section{Description}

Arm elongated, narrow; supero- and inferomarginals opposed, shortening rapidly distally (Fig. 13F-G). Superomarginals bearing single, distally directed, crater-like spine base on distal, abactinolateral margin. Supero- and inferomarginals smooth, grooves for cribriform organs between infero-/superomarginal pairs poorly defined.

\section{Remarks}

Chrispaulia wrightorum sp. nov. differs from all congeners in the smooth marginal ossicles, lacking rugosities. 
Chrispaulia spinosa sp. nov. urn:1sid:zoobank.org:act:4C003A9F-1F91-44BC-91AB-2910B8EA756A

Fig. 13D-E, H-O

\section{Diagnosis}

Chrispaulia in which distal inferomarginals bear an oblique row of large, bifid spine attachment sites, which carried long, flattened spines.

\section{Etymology}

Latin for 'bearing spines', in reference to the row of spine attachment sites on distal inferomarginals.

\section{Material examined}

A distal arm fragment (Nds LH 105.107), comprising five marginal pairs, with articulating spines preserved, is the holotype; it is from the lower Hauterivian (Endemoceras amblygonium ammonite Zone) at Engelbostel near Hannover (northern Germany). Paratypes (NHMUK PI EE 17998-18004) are 35 marginal ossicles and a single oral ossicle from the upper 3 metres of the Tealby Clay (Hauterivian) at Nettleton, Lincolnshire (United Kingdom).

\section{Description}

Arms elongated, narrow, tapering slowly (Fig. 13D-E); proximal superomarginals tall, block-like, bearing a single, abactinally directed, crater-like spine base. Central region of external face narrow, poorly defined, lateral surfaces broad with small rugosities for attachment of tiny cribriform spines (Fig. 13H-I, N; spines still articulated in Fig. 13D). Distal superomarginals with or without an abactinally situated, distally directed large spine base (Fig. 13I-J), rugose (Fig. 13D) or smooth (Fig. 13I-J). Distal infero- and superomarginals thin, imbricating proximally; distal inferomarginals with oblique row of large, bifid spine bases, which bore flattened, lanceolate spines (Fig. 13D). Sharply defined grooves for cribriform organs between each infero-/superomarginal pair. Oral ossicle (Fig. 13O) with broad actinal face, bearing large rugosities for attachment of sos; large elongate oradm, low, broad apophyse.

\section{Remarks}

Chrispaulia spinosa sp. nov. differs from its congeners in its possession of 3-4 bifid spine pits on distal inferomarginals.

Fig. 13 (next page). A-C. Chrispaulia radiatus (Spencer, 1905) (BGS 108650), arm of individual in abactinal, lateral and actinal views, respectively (the original of Gale 2005: fig. 5). - D-E, H-O. Chrispaulia spinosa sp. nov. D-E. Holotype (Nds LH 105.107), arm fragment in lateral and actinal views, respectively. H-O. Isolated ossicles, all paratypes. H-I, N. Median superomarginals (NHMUK PI EE 17998, 18003). J-K. Distal superomarginals in lateral view (NHMUK PI EE 17999-18000). L-M. Distal inferomarginals in lateral view (NHMUK PI EE 18001-18002). O. Oral ossicle, in radial aspect (NHMUK PI EE 18004). - F-G. Chrispaulia wrightorum sp. nov., holotype, reconstructed distal arm, in abactinal and lateral views, respectively (NHMUK PI EE 17997). Provenance: A-C. Cenomanian (Lower Chalk), Dover, Kent, United Kingdom. D-E. Lower Hauterivian (Endemoceras amblygonium ammonite Zone), Engelbostel near Hannover, Germany. F-G. Albian, Hunstanton Formation, Speeton, Yorkshire, United Kingdom. H-O. Upper $3 \mathrm{~m}$ of Tealby Clay, Hauterivian, Nettleton, Lincolnshire, United Kingdom. Scale bars: $\mathrm{A}-\mathrm{G}=5 \mathrm{~mm} ; \mathrm{H}-\mathrm{O}=1 \mathrm{~mm}$. 


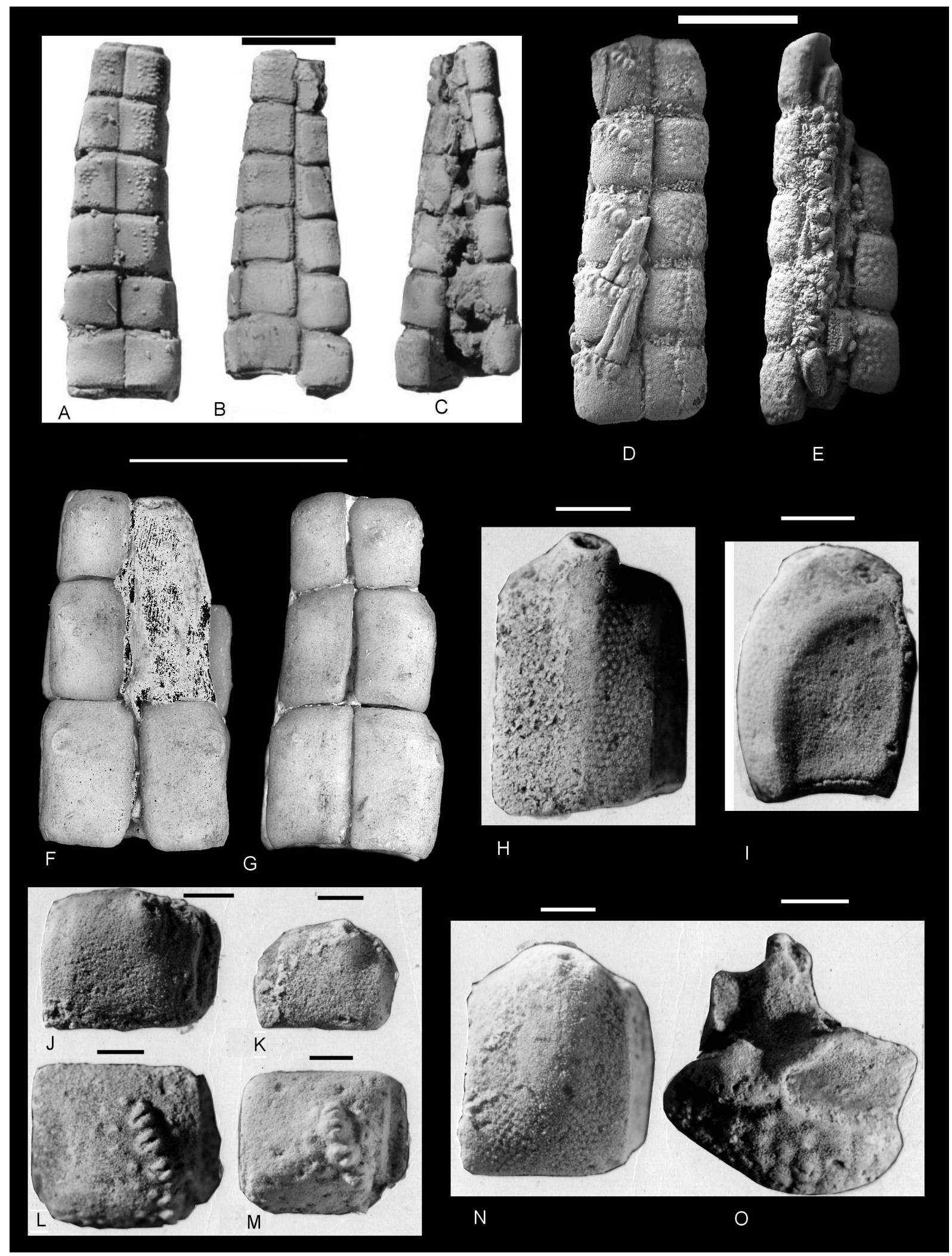


Order Spinulosida Perrier, 1884

Family Plumasteridae Gale, 2011

Plumasteridae Gale, 2011b: 82, fig. 13.

\section{Diagnosis}

Five- to multi-armed asteroids possessing broad, short concavo-convex adambulacrals which possess a single row of large, transverse spine pits; adambulacrals articulate by means of transversely arranged specialised surfaces; abactinal ossicles stellate, large, with a central boss with which a long, glassy spine articulates.

\section{Assigned genera}

Plumaster Wright, 1863 and Plesiastropecten Peyer, 1944.

\section{Remarks}

Although Plesiastropecten is 5-rayed, the adambulacrals, abactinal ossicles and marginals are closely similar to those of Plumaster (see Gale 2011b) and the genus is accommodated here.

\section{Plesiastropecten Peyer, 1944}

Plesiastropecten Peyer, 1944: 320, pls 7-8.

\section{Type species}

Plesiastropecten hallovensis Peyer, 1944, by monotypy.

\section{Diagnosis}

Five-rayed plumasterid, in which the abactinal ossicles are stellate and which bears a fringe of elongated marginal spines.

\section{Plesiastropecten hallovensis Peyer, 1944}

Fig. 14

Plesiastropecten hallovensis Peyer, 1944: 320, pls 7-8.

Plesiastropecten hallovensis - Blake 1984: 633, fig. 1a-h.

\section{Diagnosis}

As for genus.

\section{Material examined}

The holotype (MZA L13a) is a complete asteroid in a claystone matrix, comprising part and counterpart, from the Lower Jurassic (Hettangian, liasicus ammonite Zone) of Hallau, Canton Schaffhausen, Switzerland (Peyer 1944). It is contained in the collections of the Museum zu Aller Heiligen, Schaffhausen, and has suffered from considerable over-preparation. Additional material includes a suite of specimens from the same locality and horizon, most notably, specimen MZA L 13b/32a-e, which is a partially dissociated individual of which one arm is well preserved (Blake 1984: fig. 1a-g). This specimen is coated with a glue-like substance which obscures much detail and requires specialist preparation. The present description is based on these two individuals. 


\section{Description}

The overall form is well shown by the type specimen (Fig. 14A); the arms are moderately long and tapering, the interbrachial angles acute $(\mathrm{R}: \mathrm{r}=$ approximately $6: 1)$. The arms bear an even fringe of closely spaced marginal spines. The marginals are numerous, narrow and short with a three-tiered structure, resembling tiny 'cottage loaves' of bread (Fig. 14F). They are clearly visible in MZA L 13b/32a-e, and are robustly paxilliform, bearing a single large spine pit centrally. The abactinal ossicles are conspicuous and relatively large, convex to flat and carry four to six, lobe-like lateral projections. Each abactinal has a single, large and centrally placed crater-like spine pit (Fig. 14B, D). The ossicles imbricate, and the lobes are notched on their inside (actinal) surfaces for contact with adjacent ossicles. These ossicles are more or less radially symmetrical in the disc, but elongated in the arm, where the abactinal ossicles are arranged in three rows comprising radials and two adradials (Fig. 14B). In the distal arm, the large radial and adradials are separated from adjacent ossicles of the same row by smaller inset ossicles. The adambulacrals were prepared in a small part of specimen MZA L 13b/32b. They are very broad and short (3:1), and carry 5-6 large, horseshoe-shaped spine bases arranged in a single transverse row (Fig. 14E). The adambulacrals of opposing rows are slightly angled $\left(150^{\circ}\right)$ in a proximal direction. The ambulacrals are only seen in abactinal view, and the $\boldsymbol{a m b} \boldsymbol{h}$ forms a conspicuous, elongated triangular proximal wing which overlaps the more proximal adjacent ambulacral (Fig. 14D). The amb b is oval and symmetrical. The marginal spines are conspicuous, forming an even comb-like fringe to the starfish. Each marginal plate carries a single tapering spine with a unique construction. The cross section is a shallow U-shape, and the abactinal surface bears a groove. The rounded actinal surface is made up of $4-6$, length-parallel coalescing rods of trabecular stereom. The lateral margins of the spines carry outwardly directed short barbs, probably lost on the holotype through over-preparation. The base of the spine is swollen and rounded, and a simple socket on the base articulates with a boss on the marginal. The abactinal spines are shorter, and round in cross section; these are also composed of elongated trabeculae. The 5-6 adambulacral spines articulate with horseshoe-shaped bases, and are long and gently curved.

\section{Remarks}

The robust paxilliform construction of the marginals is not found in any benthopectinid asteroid, but is characteristic of modern solasterids and the Jurassic genus Plumaster, and each marginal carries only a single spine. We cannot agree with Blake (1984) that these resemble marginals of benthopectinids, other than in that they carry large spines. The large, oval or rounded, imbricating abactinal ossicles which are alternately large and spine-bearing and small and spineless in the arm are quite different from the parapaxillae of benthopectinids. The construction of the marginal and abactinal spines, with elongated trabeculae running along the length of the spines and a semicircular, concavo-convex cross section bearing two rows of lateral thorns, are dissimilar to benthopectinid spines, which are conical, cylindrical and carry numerous, irregular, distally directed thorns. The concavo-convex construction is otherwise seen only in the multi-armed Early Jurassic Plumaster ophiuroides (Wright, 1863). The transversely broad, short adambulacrals, carrying 5-6 large curved adambulacral spines, are quite unlike adambulacrals of benthopectinids which are narrow and rather elongated, but are similar to those of Plumaster (Gale 2011b: figs 13-14). The elongated, imbricating proximal flanges of the ambulacral heads are not found in any benthopectinid, where the ambulacral heads are short, upright and do not imbricate, as in all paxillosidans (Gale 2011a), but are similar to those of Plumaster (Gale 2011b: fig. 14b-c). Other than a superficial similarity in shape and the presence of elongated marginal and abactinal spines (also found in other asteroids), Plesiastropecten hallovensis does not show any of the characteristics of the Benthopectinidae, but bears a close similarity to the Pliensbachian-Aalenian multiarmed genus Plumaster, with which it shares broad, short adambulacrals with 5-6 large transversely arranged, hyaline spines and the flanged, imbricating abactinal ossicles (Gale 2011b). 


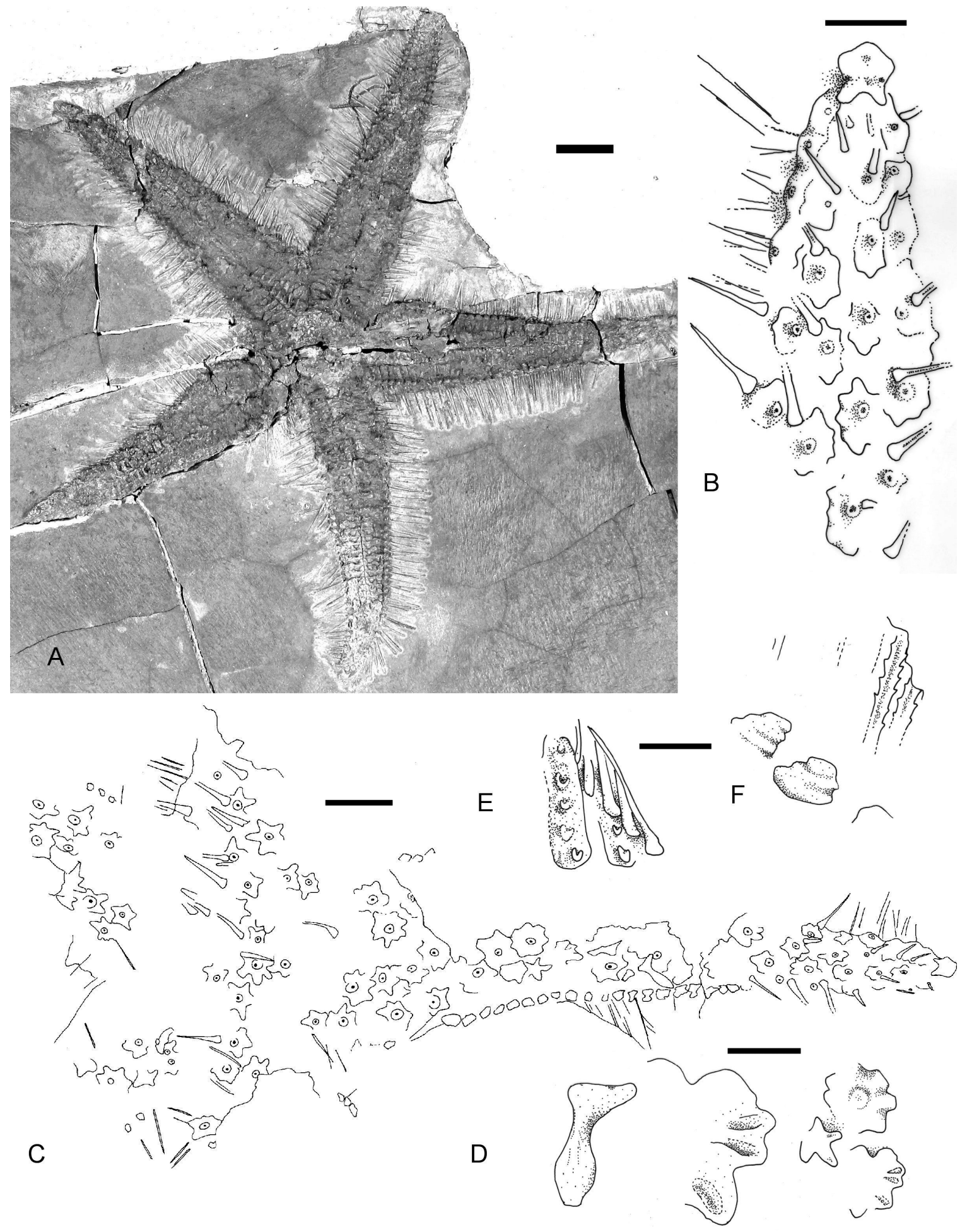

Fig. 14. Plesiastropecten hallovensis Peyer, 1944. A. Holotype (MZA L13a), the original of Peyer (1944: pl. 7) and Blake (1984: fig. 1a-h). B. Enlargement of distal arm. C-F. Line drawings of MZA L 13b/32a-e. C. Ossicle distribution of entire individual; note large, stellate abactinal ossicles which each carry a large boss for attachment of a single spine. D. Ambulacral ossicle, in abactinal view, and two abactinal ossicles. E. Adambulacral ossicle with spines attached. F. Two marginal ossicles, with serrated spines attached. Provenance: Lower Jurassic (Hettangian, liasicus ammonite Zone) of Hallau, Canton Schaffhausen, Switzerland. Scale bars: A $=10 \mathrm{~mm}$; B-C $=5 \mathrm{~mm}$; $-\mathrm{G}=2 \mathrm{~mm}$. 
GALE A.S. \& JAGT J.W.M., Fossil benthopectinids (Echinodermata, Asteroidea) reappraised

Spinulosida incertae sedis

Xandarosaster hessi Blake, 1984

Fig. $15 \mathrm{~A}-\mathrm{C}$

Xandarosaster hessi Blake, 1984: 638, figs 2a-i, 3.

\section{Material examined}

The single specimen available (NMB M9683) comprises fragments of three arms and dissociated ossicles, intimately entwined with an isocrinid crinoid on a single slab, from the Bajocian of Reigoldswil (Canton Baselland, Switzerland). The specimen is very fragmentary and is not easy to interpret, because pressure solution has welded scraps of calcite onto most ossicles, making discrimination of features difficult.

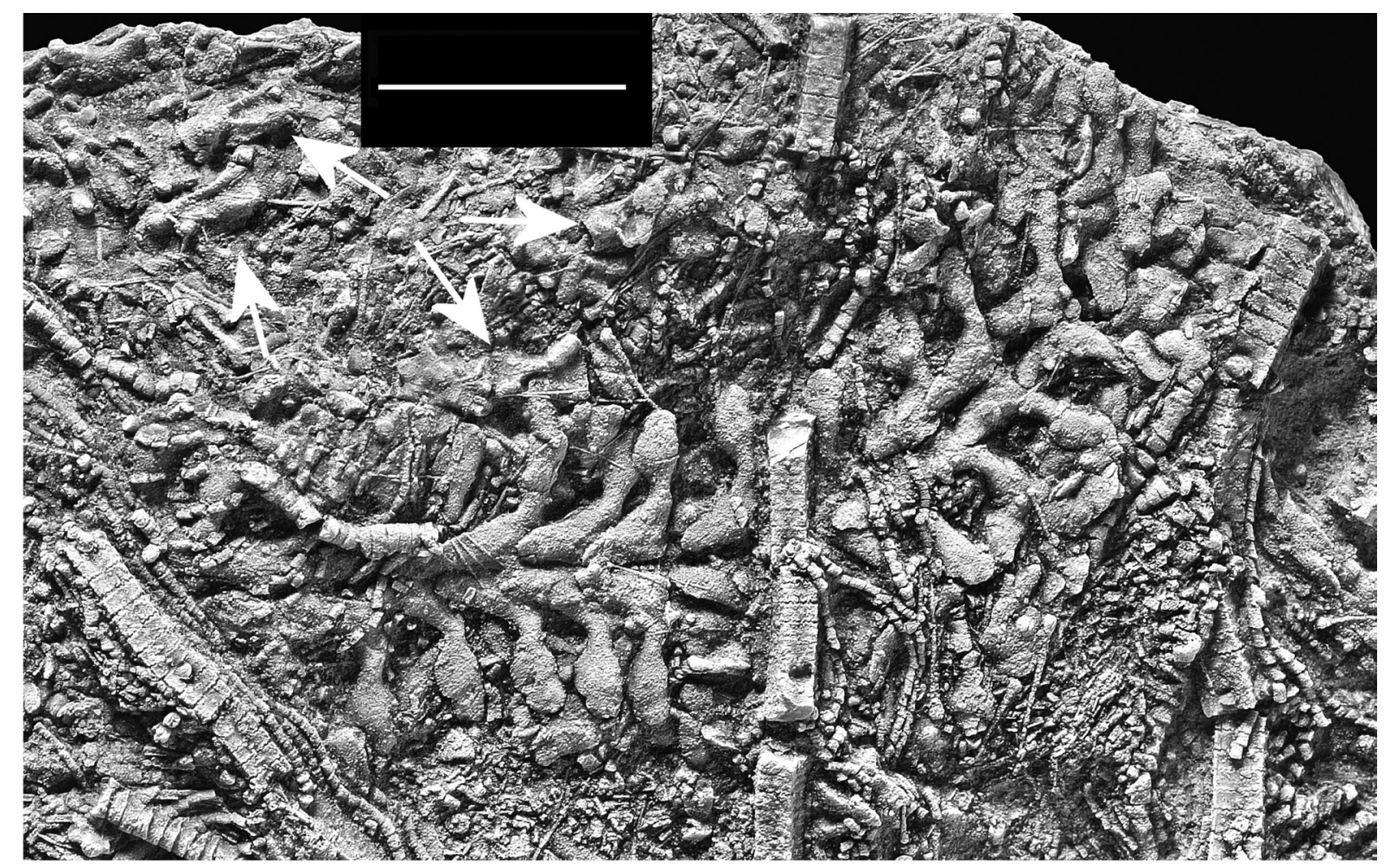
A

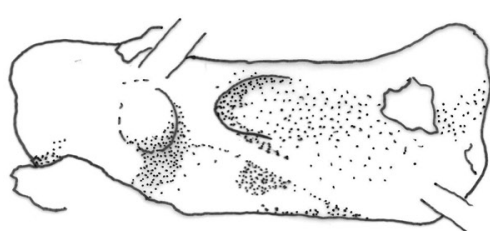

B

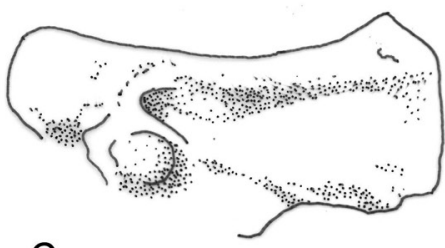

C

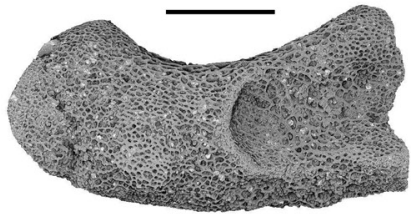

D

Fig. 15. A-C. Xandarosaster hessi Blake, 1984. A. Holotype slab (NMB M9683), showing articulated ambulacral ossicles and isolated adambulacrals (arrowed); the original of Blake (1984: fig. 2a1-3). B-C. Line drawings of actinal views of adambulacrals; note extreme elongation, long interadambulacral muscle insertion site and boss for a single, large subadambulacral spine. D. Similar adambulacral ossicle of indeterminate form (NHMUK PI EE 18008). Provenance: A-C. Bajocian of Reigoldswil, Canton Baselland, Switzerland. D. Oxfordian, Andelot-Morval, Jura, France (for details of locality, reference is made to Gale 2018: fig. 20). Scale bars: $A=10 \mathrm{~mm}$; $B-C=5 \mathrm{~mm}$; $D=0.5 \mathrm{~mm}$. 


\section{Description}

The ossicles of the ambulacral groove are the best preserved and most distinctive part of this specimen (Fig. 15A). The ambh imbricate strongly proximally, and are elongated and triangular. The ambulacrals are waisted, and the $\boldsymbol{a m b} \boldsymbol{b}$ carry short asymmetrical flanges for padam and dadam, and articulation surfaces $\boldsymbol{a d a} \mathbf{1}$ and $\boldsymbol{a d a}$. The adambulacrals are rectangular and very elongated, being approximately three times longer than broad; half to two-thirds of the actinal face is occupied by a V-shaped depression for the adadm (Fig. 15B-C). An oblique ridge runs from the proximal part of the $\mathrm{V}$ to the distal abradial margin. Proximal adambs carry two large swollen spine bases set obliquely on the proximal face of the ossicle, and more distal adamb have a single spine base.

Several oral ossicles are visible. These are very broad and gently convex on the external surface, and an adambulacral articulation ridge and deep V-shaped concavity for the oradm muscle are present. The abactinal ossicles are of even, small size, have a lobed base and carry a large centrally placed, rounded spine boss. Possible marginals are elongated-rectangular and imbricate distally, with a very large round spine base on the proximal part of the external face. The abactinal and marginal spines are conical and moderately long, and have swollen bases. They are made up of elongated trabeculae of stereom.

\section{Remarks}

The ambulacral/adambulacral articulation of $X$. hessi is utterly dissimilar to that of benthopectinids. The $\boldsymbol{a m b h}$ is broad and short in $X$. hessi, with a strong, short transverse actinal ridge. In benthopectinids, the $\boldsymbol{a} \boldsymbol{m} \boldsymbol{b} \boldsymbol{b}$ is triangular and elongated. Xandarosaster hessi has short, oval and nearly symmetrical facets for padam and dadam, which are triangular and strongly asymmetrical in benthopectinids. In X. hessi ada2 and $\boldsymbol{a d a d a}$ are fused and $\boldsymbol{a d a} 3$ is absent. In benthopectinids, all three facets are discrete, and $\boldsymbol{a d a} \mathbf{2}$ and $\boldsymbol{a d a d a}$ are placed on a ridge adjacent to a concavity on both ambulacrals and adambulacrals.

The construction of the spines, with elongated hyaline trabeculae, is unlike that of benthopectinids in which the spines are made of thorny stereom with distally directed barbs. Moreover, the elongated, strongly imbricating, asymmetrical $\boldsymbol{a m b h}$ are not present in benthopectinids, where the heads are short and do not imbricate.

In summary, $X$. hessi does not possess a single character of the Benthopectinidae, but has features unique to the Spinulosida (sensu Gale 2011a), including spines constructed of elongated hyaline trabeculae and elongated, triangular proximal $\boldsymbol{a m b h}$ which strongly imbricate proximally. Its affinity with other spinulosidans is uncertain, although some aspects of the ambulacrals and adambulacrals are broadly comparable with those of solasterids. The very elongated rectangular adambulacrals are unique to $X$. hessi. Adambulacrals of this type, currently indeterminate (Fig. 15D), are also found uncommonly in Jurassic sedimentary rocks such as the lower Oxfordian of Andelot-Morval, France.

Order Forcipulatida Perrier, 1884

Suborder Zorocallina Downey, 1970

Family Terminasteridae Gale, 2011

Terminasteridae Gale, 2011a: 92, fig. 8.

\section{Diagnosis}

Zorocallinids with extra-axial arm constructed of seven rows of ossicles organised with one row of radials, two rows of adradials, two rows of superomarginals and two rows of infromarginals; both marginal rows extend to arm tip. 
Assigned genera

Alkaidia Blake \& Reid, 1998 and Terminaster Hess, 1974.

\section{Remarks}

The family Terminasteridae is sister group to the Eocene-Recent Zoroasteridae Sladen, 1889, which is widespread in bathyal to abyssal depths of the present-day oceans.

Alkaidia Blake \& Reid, 1998

Alkaidia Blake \& Reid, 1998: 529, fig. 8.

\section{Type species}

Alkaidia sumralli Blake \& Reid, 1998, by original designation.

\section{Diagnosis}

Terminasteridae with elongated rhombic superomarginals directed obliquely towards radials; inferomarginals with tall, distally swollen central spine bases and prominent groove for spine attachment; radials (except primary radial) rhombic in outline.

\section{Assigned species}

In addition to the type species, A. megaungula Ewin \& Gale, 2020.

\section{Remarks}

Alkaidia ranges from the Barremian to Cenomanian and appears to be restricted to the western Tethys.

Alkaidia sumralli Blake \& Reid, 1998

Figs 16A-C, 17B-E, H, K

Alkaidia sumralli Blake \& Reid, 1998: 529, fig. 9/1-14.

Alkaidia sumralli - Ewin \& Gale 2020: 13, figs 10.1-10.2, 13.3, 13.8, 13.11-13.12.

\section{Diagnosis}

Alkaidia in which the primary radial ossicles are elongated and the terminal ossicle is not deeply notched on its proximal margin.

\section{Material examined}

The holotype (Texas Memorial Museum, number 1786 TX1) is from the Grayson Formation (lower Cenomanian) at the Waco shale pit (Waco, Mclennan County, Texas, USA). Additional material comprises a magnificent individual (NHMUK PI EE 15225), collected by Frank Holterhoff from the Grayson Formation (lower Cenomanian) of Dottie Lynn, Fort Worth, Texas and illustrated here (Fig. 16A-C), as well as numerous dissociated ossicles from the same locality (NHMUK PI EE 18005-18007, 18009).

\section{Remarks}

The affinities of $A$. sumralli have recently been discussed in some detail by Ewin \& Gale (2020) and the evidence for its inclusion in the Forcipulatida (Zorocallina) and the family Terminasteridae can be summarised briefly as follows: the presence of abundant, straight 'duck-billed' forcipulate pedicellariae is a characteristic of the Zorocallina (Fig. 16D); the construction of the abactinal surface is closely 

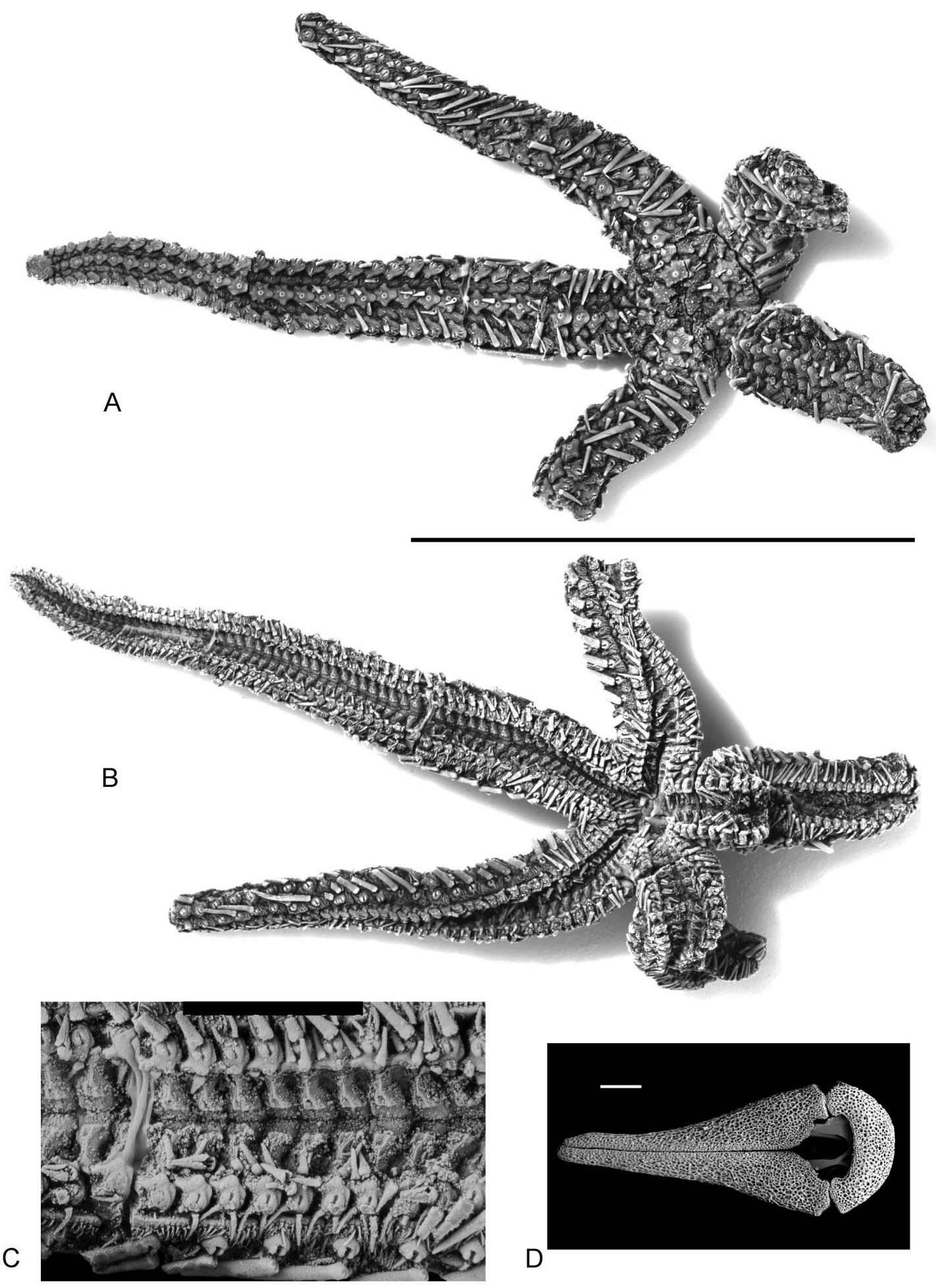

Fig. 16. A-C. Alkaidia sumralli Blake \& Reid, 1998 (NHMUK EE15225). A-B. Abactinal (A) and actinal (B) views of well-preserved individual, retaining spines and pedicellariae. C. Enlargement of ambulacral groove, showing spines and duck-bill pedicellariae. - D. Zoroaster fulgens Thomson, 1873, duck-billed pedicellaria of a zoroasterid (A.S. Gale collection, unregistered). Provenance: A-C. Grayson Formation, Graysonites wacoense ammonite Zone, Dottie Lynn Lane, Fort Worth, Texas, USA (for details of locality, reference is made to Hess 2015 and Gale et al. 2021). D. Recent, Rockall Trough, northeast Atlantic. Scale bars: A-B $=50 \mathrm{~mm} ; \mathrm{C}=5 \mathrm{~mm} ; \mathrm{D}=0.5 \mathrm{~mm}$. 


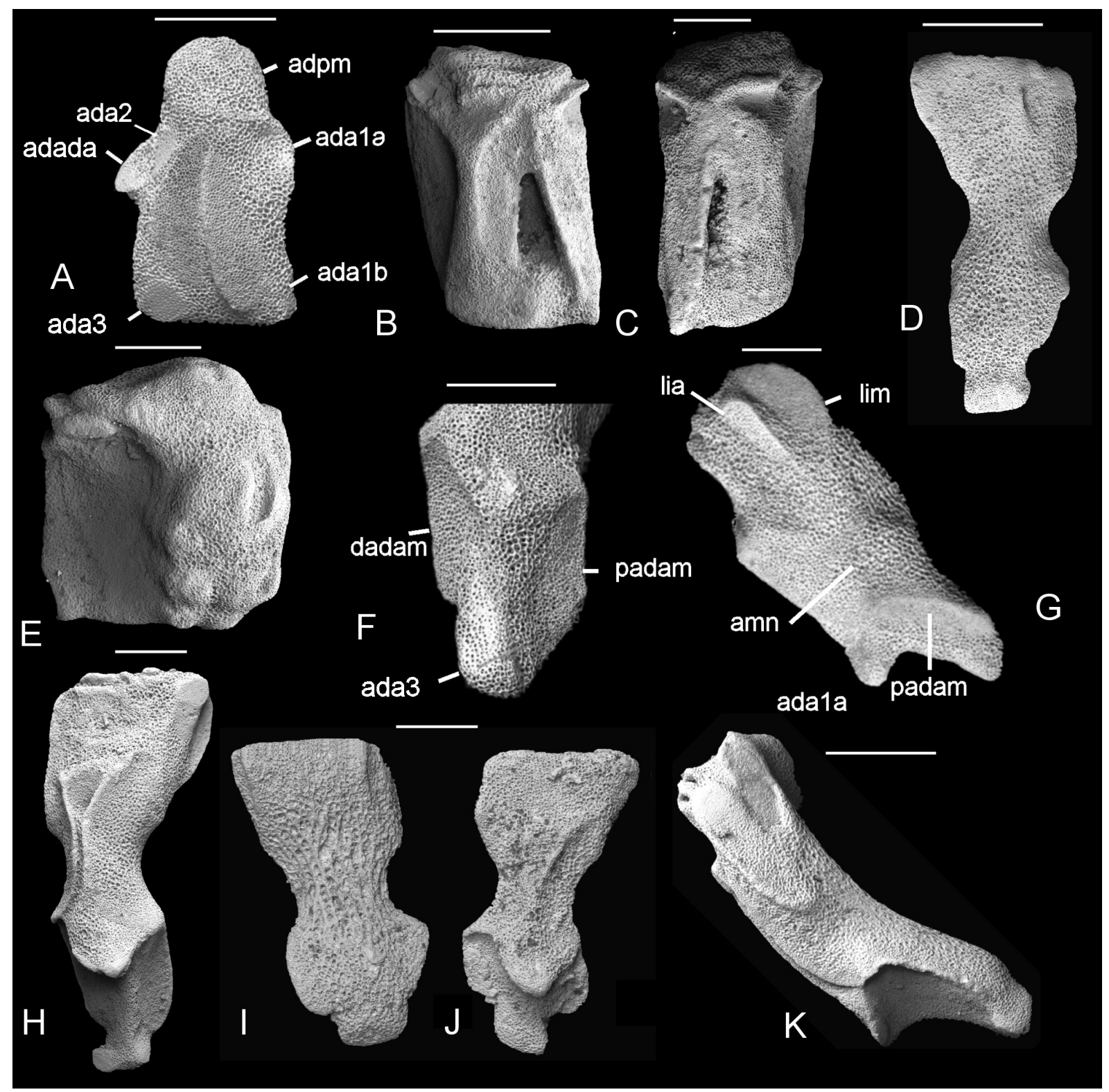

Fig. 17.A, F-G. Zoroaster fulgens Thomson, 1873 (A.S. Gale collection, unregistered). A. Adambulacral, in abactinal view; the original of Gale (2011a: pl. 8 fig. 5). F. Ambulacral base, in actinal view; the original of Gale (2011a: pl. 8 fig. 8). G. Ambulacral, in proximal view. - B-E, H, K. Alkaidia sumralli Blake \& Reid, 1998, isolated ambulacrals and adambulacrals. B-C. Abactinal views of adambulacrals (NHMUK PI EE 18005-18006). D. Abactinal view of ambulacral (NHMUK PI EE 18007). E. Actinal view of adambulacral (NHMUK PI EE 18008). H. Actinal view of ambulacral (NHMUK PI EE 18008). K. Proximal view of ambulacral (NHMUK PI EE 18010), the original of Gale (2011a: pl. 8 fig. 9). I-J. Terminaster cancriformis (Quenstedt, 1876) (NMB M 9036), ambulacral, in abactinal and actinal views; the original of Gale (2011a: pl. 26 figs 11-12). Provenance: A, F-G. Recent, Rockall Trough, northeast Atlantic. B-E, H, K. Grayson Formation, Graysonites wacoense ammonite Zone, Dottie Lynn Lane, Fort Worth, Texas, USA (for locality details, reference is made to Hess 2015 and Gale et al. 2021). I-J. Upper Oxfordian (Couches d'Effingen, bifurcatus ammonite Zone, stenocycloides ammonite Subzone), Savigna, near Orgelet, Département de Jura, France (Gale 2011b). See Material and methods for abbreviations. Scale bars: $1 \mathrm{~mm}$. 
similar to that of zoroasterids and terminasterids, which also have large, Y-shaped first superomarginals and a row of robust, lobed, quadrangular radial ossicles which imbricate proximally and each carry a centrally placed conical spine (Ewin \& Gale 2020).

Additionally, the morphology of the adambulacrals and ambulacrals, and the nature of their articulation is similar in zoroasterids, Terminaster and Alkaidia (Fig. 17). Ada1a and ada2 are concave on the adamulacrals (Fig. 17A-C) and positioned on a process on the ambulacrals (Fig. 17G-H, J-K). The dadam and padam facets are subequal in size, broad and short (Fig. 17A-C).

The abactinal construction is never seen in extant benthopectinids, in which the abactinal ossicles in the arms are small and parapaxilliform or very small, and never imbricate. Additionally, in benthopectinids the abactinal surface is invariably flat, and the arm section is not subcylindrical.

Indeterminate asteroid

Henricia? venturana Durham \& Roberts, 1948

Henricia? venturana Durham \& Roberts, 1948: 437, pl. 66 figs 1, 3.

\section{Remarks}

The unique holotype, from the Upper Cretaceous Chico Formation of the North Fork of Matilija Creek, Ventura County (California, USA), is contained in the palaeontological collections of the University of California. Part (number 4866B) and counterpart (4866A) show the abactinal and actinal surfaces, respectively.

The type specimen is an external mould of a near-complete asteroid with moderately long, narrow arms and a small disc, which has lost the abactinal ossicles and exposes the ambulacrals on the abactinal surface. Unfortunately, parts of the moulds have been worn by erosion and few details are well preserved. The ambulacral heads are elongated, and the adambulacral ossicles are clearly visible, as are probable small marginal ossicles bearing spines. The groove is very wide. Although Blake (1984) assigned the taxon to the Benthopectinidae, there does not seem to be any compelling evidence for its taxonomic affinity, and it is considered here to be an indeterminate asteroid.

\section{Discussion}

The hypothesis that Mesozoic asteroids (Table 2) which bear conspicuous, elongated marginal and abactinal spines are members of, or closely related to, the extant deep-sea family Benthopectinidae is tested, using comparative morphology of diverse ossicle types. It is concluded that all three members of the subfamily Paleobenthopectininae Blake, 1984 are convergent in gross morphology with certain extant benthopectinids and should be correctly assigned to distantly related groups (i.e., Spinulosida, Plumasteridae; Forcipulatida, Terminasteridae). The other fossil benthopectinid cited in the literature (Spencer \& Wright, 1966) is here assigned to a new species of the goniopectinid genus Chrispaulia.

In the present study, we demonstrate the taxonomic value of characters ubiquitously present in extant benthopectinids. In particular, the ambulacral/adambulacral morphology is of value, specifically the nature of the articulation between the ambulacrals and adambulacrals; this provides an excellent criterion for correct recognition of fossil benthopectinids (see also Gale 2011a). The distinctive benthopectinid ambulacral/adambulacral articulation appeared early in the Jurassic (Toarcian) and is retained in all members of the family to the present day. Possible benthopectinid ossicles are already present in the Triassic (see above), but in the absence of ossicles of the ambulacral groove and mouth frame this identification is uncertain. 
GALE A.S. \& JAGT J.W.M., Fossil benthopectinids (Echinodermata, Asteroidea) reappraised

Table 2. Affinities of fossils assigned to the Benthopectinidae Verrill, 1894, by date of publication.

\begin{tabular}{|c|c|c|c|}
\hline Name & Age & Locality & Assignation \\
\hline $\begin{array}{l}\text { Plesiastropecten } \\
\text { hallovensis Peyer, } 1944\end{array}$ & $\begin{array}{l}\text { Early Jurassic } \\
\text { Hettangian }\end{array}$ & Switzerland & $\begin{array}{l}\text { Spinulosida, } \\
\text { Plumasteridae }\end{array}$ \\
\hline $\begin{array}{l}\text { Henricia ? venturana } \\
\text { Durham \& Roberts, } 1948\end{array}$ & Cretaceous & California & Indeterminate asteroid \\
\hline $\begin{array}{l}\text { Benthopectinid } \\
\text { Spencer \& Wright } 1966\end{array}$ & Albian & Yorkshire, England & $\begin{array}{c}\text { Goniopectinidae, } \\
\text { Chrispaulia wrightorum } \\
\text { sp. nov. }\end{array}$ \\
\hline $\begin{array}{l}\text { Mistia spinosa } \\
\text { Blake, } 1973\end{array}$ & Oligocene & Mist, California & $\begin{array}{l}\text { Benthopectinidae, } \\
\text { Nearchaster } \\
\text { spinosus }\end{array}$ \\
\hline $\begin{array}{l}\text { Xandarosaster hessi } \\
\text { Blake, } 1984\end{array}$ & $\begin{array}{l}\text { Middle Jurassic, } \\
\text { Bajocian }\end{array}$ & Switzerland & $\begin{array}{c}\text { Spinulosida, affinity } \\
\text { uncertain }\end{array}$ \\
\hline $\begin{array}{l}\text { Alkaidia sumralli } \\
\text { Blake \& Reid, } 1998\end{array}$ & $\begin{array}{c}\text { Cretaceous, } \\
\text { Albian-Cenomanian }\end{array}$ & Texas & $\begin{array}{l}\text { Forcipulatida, } \\
\text { Terminasteridae }\end{array}$ \\
\hline $\begin{array}{l}\text { Benthopectinid } 1 \\
\text { Jagt } 2000\end{array}$ & Late Cretaceous & Netherlands & $\begin{array}{l}\text { Benthopectinidae, } \\
\text { Jurapecten dhondtae } \\
\text { sp. nov. }\end{array}$ \\
\hline $\begin{array}{l}\text { Benthopectinid } 2 \\
\text { Jagt } 2000\end{array}$ & $\begin{array}{l}\text { Late Cretaceous, } \\
\text { Cenomanian-- } \\
\text { Maastrichtian }\end{array}$ & $\begin{array}{l}\text { Netherlands, UK, } \\
\text { Denmark, Germany, } \\
\text { Czech Republic }\end{array}$ & $\begin{array}{l}\text { Benthopectinidae, } \\
\text { Punkaster spinifera } \\
\text { gen. et sp. nov. }\end{array}$ \\
\hline
\end{tabular}

The Benthopectinidae is represented in the Jurassic and Cretaceous (Toarcian-Maastrichtian) by the genus Jurapecten, which resembles the extant Pontaster in the morphology of the marginal plates and spines attached to these (squat, block-like; spines short), but in which the ambulacrals lack a raised transverse abactinal ridge; they did not articulate with the inferomarginals, as is the case in all extant genera. The absence of the abactinal ridge can be taken as evidence that Jurapecten lacked longitudinal muscles in the arm. The new genus Punkaster gen. nov., from the Upper Cretaceous, appears to be a highly derived benthopectinid, in which the marginals are elongated, sometimes in fused interradial pairs, and carried large conical spines. The main evidence of assignation of Punkaster gen. nov. to the family is the nature of the ambulacral/adambulacral articulation. The oldest representative of extant benthopectinid genera is Nearchaster (formerly Mistia) spinosus comb. nov. from the Lower Oligocene of Oregon, USA (Blake 1973).

The transition between the plesiomorphic Mesozoic-type benthopectinid morphologies (lack of abactinal ridges on ambulacrals, ambulacrals not articulating with the inferomarginals) and derived Cenozoic types in which the abactinal ridges supported longitudinal muscles, is poorly known, but the oldest Cenozoic fossil benthopectinid (Nearchaster spinosus comb. nov.) is present in the Early Oligocene. It is therefore likely that the radiation of the family took place during the early Paleogene. The presence of a number of derived characters in all living and Cenozoic benthopectinid taxa supports their monophyly. However, the very fragmentary nature of the benthopectinid fossil record (mostly isolated ossicles) does not lend itself to cladistic analysis of the group. 


\section{Acknowledgements}

The senior author is grateful to Ben Thuy (Luxemburg) and the late Hans Hess for help with finding localities, and to Christine Hughes for allowing the use of the SEM in Biological Sciences, University of Portsmouth; the junior author acknowledges the support of private collectors and quarry managements for permission to do fieldwork in the Maastrichtian type area (Belgium, the Netherlands) over many years. We are grateful to the referees for their detailed comments.

\section{References}

Blake D.B. 1973. Ossicle morphology of some Recent asteroids and description of some West American fossil asteroids. University of California Publications in Geological Sciences 104: 1-59.

Blake D.B. 1984. The Benthopectinidae (Aseroidea: Echinodermata) of the Jurassic of Switzerland. Eclogae geologicae Helvetiae 77 (3): 631-647.

Blake D.B. \& Jagt J.W.M. 2005. New latest Cretaceous and earliest Paleogene asteroids (Echinodermata) from The Netherlands and Denmark and their palaeobiological significance. Bulletin de l'Institut royal des Sciences naturelles de Belgique, Sciences de la Terre 75: 183-200.

Blake D.B. \& Reid R. III. 1998. Some Albian (Cretaceous) asteroids (Echinodermata) from Texas and their paleobiological implications. Journal of Paleontology 72 (3): 512-532.

https://doi.org/10.1017/S002233600002429X

Bruguière J.G. 1791. Tableau encyclopédique et méthodique des trois règnes de la nature. L'Helminthogie 17: 1-83.

Clark A.M. 1981. Notes on Atlantic and other Asteroidea. 1. Family Benthopectinidae. Bulletin of the British Museum of Natural History (Zoology) 41: 91-135.

Clark A.M. \& Downey M.E. 1992. Starfishes of the Atlantic. Chapman \& Hall, London.

De Blainville H.M.D. 1830. Zoophytes. Dictionnaire des Sciences naturelles 60: 1-546.

Durham J.W. \& Roberts W.A. 1948. Cretaceous asteroids from California. Journal of Paleontology 22: $432-439$.

Ewin T.A.M. \& Gale A.S. 2020. Asteroids (Echinodermata) from the Barremian (Lower Cretaceous) of the Agadir Basin, west Morocco. Journal of Paleontology 94 (5): 931-954.

https://doi.org/10.1017/jpa.2020.20

Fisher W.K. 1911. Asteroidea of the North Pacific and adjacent waters. Part 1. Phanerozonia and Spinulosa. Bulletin of the United States National Museum 76: 1-420. https://doi.org/10.5479/si.03629236.76.i

Gage J.D., Pearson M., Clark A.M., Paterson G.L.J. \& Tyler P.A. 1982. Echinoderms of the Rockall Trough and adjacent areas. 1. Crinoidea, Asteroidea and Ophiuroidea. Bulletin of the British Museum Natural History (Zoology) 45: 263-308. https://doi.org/10.5962/bhl.part.28002

Gale A.S. 1980. Penecontemporaneous folding, sedimentation and erosion in Campanian Chalk near Portsmouth, England. Sedimentology 27: 137-151. https://doi.org/10.1111/j.1365-3091.1980.tb01165.x

Gale A.S. 2005. Chrispaulia, a new genus of mud star (Asteroidea, Goniopectinidae) from the Cretaceous of England. Geological Journal 40: 383-397. https://doi.org/10.1002/gj.1019

Gale A.S. 2011a. The phylogeny of post-Palaeozoic Asteroidea (Neoasteroidea, Echinodermata). Special Papers in Palaeontology 85: 1-112.

Gale A.S. 2011b. Asteroidea (Echinodermata) from the Oxfordian (Late Jurassic) of Savigna, Départment [sic] du Jura, France. In: Meyer C.A. \& Costeur L. (eds) Special Issue: Echinoderms - from the early 
GALE A.S. \& JAGT J.W.M., Fossil benthopectinids (Echinodermata, Asteroidea) reappraised

past to the near future. A tribute to Hans Hess on his $80^{\text {th }}$ birthday. Swiss Journal of Palaeontology 130: 69-89. https://doi.org/10.1007/s13358-010-0008-x

Gale A.S. 2018. Origin and phylogeny of the velatid asteroids (Echinodermata, Neoasteroidea) - new evidence from the Jurassic. Swiss Journal of Palaeontology 137: 279-318.

https://doi.org/10.1007/s13358-018-0155-z

Gale A.S., Rashall J.M., Kennedy W.J. \& Holterhoff F. 2021. The microcrinoid taxonomy, biostratigraphy and correlation of the upper Fredericksburg and Lower Washita groups (Cretaceous, middle Albian to lower Cenomanian) of northern Texas and southern Oklahoma, USA. Acta Geologica Polonica 71 (1): $1-52$.

Hess H. 2014. Origin and radiation of the comatulids (Crinoidea) in the Jurassic. Swiss Journal of Palaeontology 133: 23-34. https://doi.org/10.1007/s13358-013-0061-3

Hess H. 2015. Roveacrinids (Crinoidea) from the mid-Cretaceous of Texas: ontogeny, phylogeny, functional morphology, lifestyle. Swiss Journal of Palaeontology 134: 77-107.

https://doi.org/10.1007/s13358-015-0076-z

Jagt J.W.M. 1999. An overview of Late Cretaceous and Early Palaeogene echinoderm faunas from LiègeLimburg (Belgium, The Netherlands). In: Dhondt A.V. \& Alekseev A.S. (eds) D.P. Naidin Festschrift (INTAS 94-1414). Bulletin de l'Institut royal des Sciences naturelles de Belgique, Sciences de la Terre 69 (Supplement A): 103-118.

Jagt J.W.M. 2000. Late Cretaceous-Early Palaeogene echinoderms and the K/T boundary in the southeast Netherlands and northeast Belgium - Part 5: Asteroids. Scripta Geologica 121: 377-503.

Jangoux M. \& Lambert A. 1988. Étude comparative des pédicellaires des astérides (échinodermes). Bulletin de la Société scientifique et naturaliste de l'Ouest de France, Supplément hors-série: 47-56.

Keutgen N. 2018. A bioclast-based astronomical timescale for the Maastrichtian in the type area (southeast Netherlands, northeast Belgium) and stratigraphic implications: the legacy of P.J. Felder. Netherlands Journal of Geosciences 97: 229-260. https://doi.org/10.1017/njg.2018.15

Mah C.L. 2020a. World Asteroidea Database. Notomyotida. World Register of Marine Species. Available from http://www.marinespecies.org/aphia.php?p=taxdetails\&id=123087 [accessed 11 Apr. 2020].

Mah C.L. 2020b. New species, occurrence records and observations of predation by deep-sea Asteroidea (Echinodermata) from the North Atlantic by NOAA ship Okeanos Explorer. Zootaxa 4766 (2): 201-260. https://doi.org/10.11646/zootaxa.4766.2.1

Mah C.L. \& Foltz D.W. 2011. Molecular phylogeny of the Forcipulatacea (Asteroidea: Echinodermata): systematics and biogeography. Zoological Journal of the Linnean Society 162: 646-660.

https://doi.org/10.1111/j.1096-3642.2010.00688.x

Müller A.H. 1953. Die isolierten Skelettelemente der Asteroidea (Asterozoa) aus der obersenonen Schreibkreide von Rügen. Geologie, Beiheft 8: 3-66.

Peyer B. 1944. Beiträge zur Kenntnis von Rhät und Lias. Eclogae geologicae Helvetiae 36: 303-326.

Spencer W.K. \& Wright C.W. 1966. Asterozoans. In: Moore R.C. (ed.) Treatise on Invertebrate Paleontology, Part U, Echinodermata 3: U4-U107. The Geological Society of America and The University of Kansas Press, Boulder, CO and Lawrence, KS.

Surlyk F., Damholt T. \& Bjerager M. 2006. Stevns Klint, Denmark: uppermost Maastrichtian chalk, Cretaceous-Tertiary boundary, and lower Danian bryozoan mound complex. Bulletin of the Geological Society of Denmark 54: 1-48. https://doi.org/10.37570/bgsd-2006-54-01 
Thuy B. 2012. Ophiacanthid Brittle Stars (Echinodermata: Ophiuroidea) as a Model Organism to explore the Origin and Evolution of the modern Deep-Sea Fauna. PhD thesis, Georg-August-Universität zu Göttingen, Mathematisch-naturwissenschaftliche Fakultät, Göttingen.

Verrill A.E. 1894. Descriptions of new species of starfishes and ophiurans, with a revision of certain species formerly described; mostly from the collections made by the United States Commission of Fish and Fisheries. Proceedings of the United States National Museum 17 (1000): 245-297. https://doi.org/10.5479/si.00963801.1000.245

Villier L., Charbonnier S. \& Riou B. 2009. Sea stars from the Middle Jurassic Lagerstätte of La Voultesur-Rhône (Ardèche, France). Journal of Paleontology 83: 389-398. https://doi.org/10.1666/08-030.1

Zullo V.A., Kaar R.F., Durham J.W. \& Allison E.C. 1964. The echinoid genus Salenia in the eastern Pacific. Palaeontology 7: 331-349.

Manuscript received: 7 July 2020

Manuscript accepted: 1 May 2021

Published on: 23 June 2021

Topic editor: Christian de Muizon

Desk editor: Kristiaan Hoedemakers

Printed versions of all papers are also deposited in the libraries of the institutes that are members of the EJT consortium: Muséum national d'histoire naturelle, Paris, France; Meise Botanic Garden, Belgium; Royal Museum for Central Africa, Tervuren, Belgium; Royal Belgian Institute of Natural Sciences, Brussels, Belgium; Natural History Museum of Denmark, Copenhagen, Denmark; Naturalis Biodiversity Center, Leiden, the Netherlands; Museo Nacional de Ciencias Naturales-CSIC, Madrid, Spain; Real Jardín Botánico de Madrid CSIC, Spain; Zoological Research Museum Alexander Koenig, Bonn, Germany; National Museum, Prague, Czech Republic. 